\title{
The effects of aggressive mitigation on steric sea level rise and sea ice changes
}

\author{
J. Körper · I. Höschel · J. A. Lowe · C. D. Hewitt · D. Salas y Melia • \\ E. Roeckner $\cdot$ H. Huebener $\cdot$ J.-F. Royer $\cdot$ J.-L. Dufresne $\cdot$ A. Pardaens $\cdot$ \\ M. A. Giorgetta $\cdot$ M. G. Sanderson $\cdot$ O. H. Otterå $\cdot$ J. Tjiputra $\cdot$ S. Denvil
}

Received: 9 May 2011/ Accepted: 22 November 2012/Published online: 12 December 2012

(C) The Author(s) 2012. This article is published with open access at Springerlink.com

\begin{abstract}
With an increasing political focus on limiting global warming to less than $2{ }^{\circ} \mathrm{C}$ above pre-industrial levels it is vital to understand the consequences of these targets on key parts of the climate system. Here, we focus on changes in sea level and sea ice, comparing twenty-first century projections with increased greenhouse gas concentrations (using the mid-range IPCC A1B emissions scenario) with those under a mitigation scenario with large reductions in emissions (the E1 scenario). At the end of the twenty-first century, the global mean steric sea level rise is reduced by about a third in the mitigation scenario compared with the A1B scenario. Changes in surface air temperature are found to be poorly correlated with steric sea level changes. While the projected decreases in sea ice extent during the first half of the twenty-first century are independent of the season or
\end{abstract}

J. Körper $(\bowtie) \cdot$ I. Höschel

Institut für Meteorologie, Freie Universität Berlin, Carl-Heinrich-Becker-Weg 6-10, 12165 Berlin, Germany

e-mail: janina.koerper@met.fu-berlin.de

J. A. Lowe - C. D. Hewitt - A. Pardaens - M. G. Sanderson Met Office Hadley Centre, Fitzroy Road,

Exeter EX1 3PB, UK

D. Salas y Melia $\cdot$ J.-F. Royer

Centre National de Recherches Météorologiques-Groupe

d'Etude de l'Atmosphère Météorologique (CNRM-GAME

Meteo-France CNRS), 42 Avenue G. Coriolis,

31057 Toulouse, France

E. Roeckner - M. A. Giorgetta

Max-Planck-Institut für Meteorologie,

Bundesstrasse 53, 20146 Hamburg, Germany

H. Huebener

Hessian Agency for Environment and Geology,

Rheingaustraße 186, 65203 Wiesbaden, Germany scenario, especially in the Arctic, the seasonal cycle of sea ice extent is amplified. By the end of the century the Arctic becomes sea ice free in September in the A1B scenario in most models. In the mitigation scenario the ice does not disappear in the majority of models, but is reduced by $42 \%$ of the present September extent. Results for Antarctic sea ice changes reveal large initial biases in the models and a significant correlation between projected changes and the initial extent. This latter result highlights the necessity for further refinements in Antarctic sea ice modelling for more reliable projections of future sea ice.

Keywords Climate $\cdot$ Projections - Stabilization .

Sea level rise $\cdot$ Sea ice $\cdot$ Multi-model $\cdot$ ENSEMBLES CMIP5 $\cdot$ Mitigation

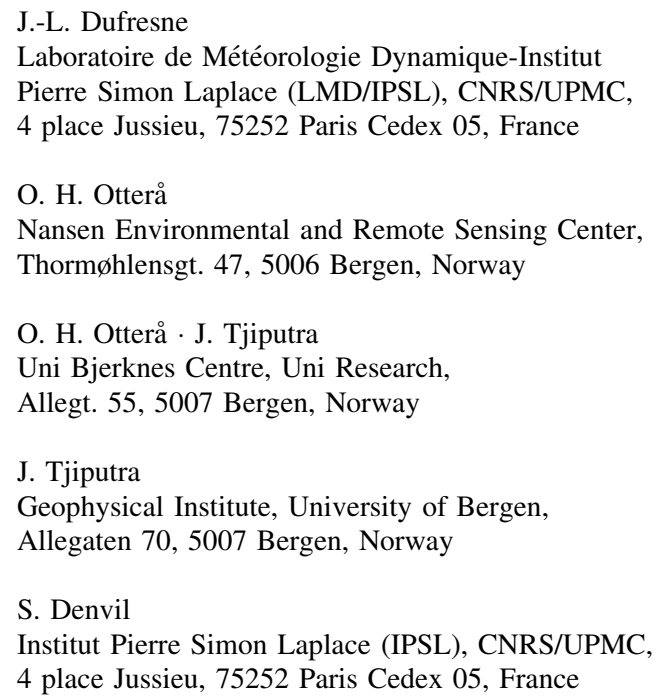




\section{Introduction}

Climate change and its adverse effects are of global concern. Article 2 of the United Nations Framework Convention on Climate Change (UNFCCC) states that the ultimate objective is the "stabilization of greenhouse gas (GHG) concentrations in the atmosphere at a level that would prevent dangerous anthropogenic interference with the climate system" (UNFCCC 1992). Furthermore, as part of this aim, it is now widely accepted that global mean warming needs to be limited to $2{ }^{\circ} \mathrm{C}$ or less compared with the pre-industrial era (as recognized in the Cancun Agreements and the Copenhagen Accord). In order to inform policy makers as well as the general public, one of the goals of climate research is to investigate future scenarios for the twenty-first century that might achieve the goal of limiting global warming to $2{ }^{\circ} \mathrm{C}$.

Within the ENSEMBLES project (Hewitt and Griggs 2004) a mitigation scenario named $E 1$ was designed that would result in a global mean surface air temperature increase of less than $2{ }^{\circ} \mathrm{C}$ (Lowe et al. 2009). This scenario complements the representative concentration pathways (RCPs) of the ongoing Coupled Model Intercomparison Project Phase 5 (CMIP5; Taylor et al. 2009).

While there is a strong focus on the global average temperature rise under mitigation, less attention has been paid to one of the most critical aspects of a warming climate: that is, sea level change due to thermal expansion of the oceans and the melting of land ice (ice sheets and glaciers). Sea levels will adjust to radiative forcing on time scales up to millennia. One of the consequences of a significant rise in sea level is that millions of additional people, mostly in highly populated coastal areas of Asia and Africa, as well as residents of small islands, are projected to experience floods every year by the 2080s (Nicholls et al. 2007). Furthermore, owing to the slow response of the ocean to changes in the radiative forcing, mitigation alone will not be able to negate all impacts, and some adaptation will be needed (Nicholls and Lowe 2004). Consequently, the effect of mitigation on sea level rise is expected to be weaker than for other climate parameters such as surface air temperature (e.g. Lowe et al. 2006; Meehl et al. 2012).

Sea level rise occurs owing to thermal expansion of the ocean waters and melting of land-based ice. The models used in the present study do not include simulations of melting of land ice. In this study, we focus on thermal expansion and its effect on sea level rise and refer to it as "steric" sea level rise for simplicity, noting that halosteric effects have little impact on global average sea levels. Very briefly, we consider another aspect of the longer-term potential contribution to sea level rise from complete melting of the Greenland ice sheet (GIS). Gregory and
Huybrechts (2006) and Robinson et al. (2012) have estimated the threshold of global mean surface temperature increase that could give eventual de-glaciation of the GIS, over subsequent millennia. Based on the global mean near surface temperature projections, we comment on the likelihood of exceeding such a threshold under the two scenarios.

Another important consideration is the effect of mitigation on changes in sea ice. The Arctic is particularly sensitive to warming; sea ice changes, especially during summer, may lead to a strong positive feedback on temperature, which will have many regional consequences, for example on biodiversity, tourism, and new shipping routes.

Several studies have attempted to provide information on the climate response to mitigation scenarios. For instance, the ECHAM5-MPIOM model was used in an idealized experimental setup in which well-mixed GHG concentrations for the year 2020 (from the A1B scenario) were prescribed. In addition, the model was forced with fixed stratospheric ozone levels and sulfate loading from the year 2100 of the A1B scenario. The resulting warming did not exceed $2{ }^{\circ} \mathrm{C}$ above the pre-industrial era (May 2008). The typical features of other climate scenarios were simulated in this experiment, including the amplified Northern Hemisphere high latitude warming accompanied by a marked reduction of the sea-ice cover, which appears remarkably strong with regard to the magnitude of global mean warming (May 2008).

Washington et al. (2009) used the Community Climate System Model to estimate aspects of the effect of mitigation on climate change using a low emission mitigation scenario (Clarke et al. 2007). They found a reduction of global mean warming of $1.2{ }^{\circ} \mathrm{C}$ (with about $2.2{ }^{\circ} \mathrm{C}$ global mean warming by 2080-2099 relative to $1980-1999$ without mitigation and about $1{ }^{\circ} \mathrm{C}$ in the mitigation scenario), and an avoided thermal expansion of $8 \mathrm{~cm}$ (with $22 \mathrm{~cm}$ thermal expansion without mitigation and $14 \mathrm{~cm}$ in the mitigation case). Moreover, about $50 \%$ of the Arctic present day sea ice extent, i.e. four million square kilometers, was preserved in their mitigation simulations.

Employing the GISS climate model, Hansen et al. (2007) studied to what extent dangerous interference with the climate system may be realistically avoided. In their regional analysis of the Arctic they find a clear distinction between the A1B scenario and the "alternative" scenario (Hansen and Sato 2004) that leads to a temperature rise of about $1{ }^{\circ} \mathrm{C}$ relative to today. They point out that a warming of less than $1{ }^{\circ} \mathrm{C}$ (relative to today) does not unleash a strong positive feedback, while in the "business-as-usual" scenarios warming would extend far outside the range of recent interglacial periods, thereby raising the possibility of much larger feedbacks such as destabilization of methane hydrates. 
Building on the work by Hansen et al. (2007), May (2008), and Washington et al. (2009) this study investigates the possibility of reducing dangerous anthropogenic interference with the climate system by analyzing results from the ENSEMBLES multi-model experiments for the period 1860-2100. By comparing results for the A1B scenario, which assumes no mitigation measures, with the E1 scenario, which includes aggressive mitigation measures (further details are given in Sect. 2.2), the possible effects of mitigation on the climate system can be evaluated. An analysis of the ENSEMBLES experiments by Johns et al. (2011) focused on global mean temperature and precipitation changes as well as on the implied carbon emissions. Our analysis focuses on two additional key aspects of climate change: steric sea level rise and sea ice change.

The paper is structured as followed. A brief description of the models employed in this study and of the scenario design is given in Sect. 2. Section 3 focuses on steric sea level change in the two scenarios. In Sect. 4 results on seasonal sea ice changes are presented. Finally, the results are discussed and conclusions drawn (Sect. 5).

\section{Models and experimental design}

\subsection{Models}

Results presented in this study are based on the multimodel experiment from 1860 to 2100 within ENSEMBLES. The participating atmosphere-ocean general circulation models (AOGCMs) and Earth System models are improved or extended versions of those that contributed to the WCRP CMIP3 project that contributed to the Working Group I contribution to IPCC Fourth Assessment Report (Solomon et al. 2007), henceforth referred to as AR4. All models include an ocean and an atmospheric component as well as a sea-ice model. Only the EGMAM+ and HadCM3C models use flux adjustment. A detailed description of the models is given by Johns et al. (2011); here, the main components of the models are summarized.

- The HadGEM2-AO model is based on the HadGEM1 model used in IPCC AR4, described by Johns et al. (2006), but contains several improvements and modifications (Collins et al. 2011b). For steric expansion model drift is removed by taking into account the linear trend in the control simulation.

- The HadCM3C model is a modified configuration of the HadCM3 model (Gordon et al. 2000) as used in IPCC AR4, but with a number of differences that are described in Collins et al. (2011a). It is run with flux adjustment. Additionally, a fully interactive land surface model (Essery et al. 2003), the TRIFFID dynamic vegetation model (Cox 2001), and an ocean carbon cycle model (Palmer and Totterdell 2001) are also included. For steric expansion model drift is removed by taking into account the linear trend in the control simulation.

- In the AOGCM IPSL-CM4 (Marti et al. 2010) the LMDZ4 atmosphere (Hourdin et al. 2006), the ORCHIDEE land and vegetation (Krinner et al. 2005), the OPA8.2 ocean (Madec et al. 1999) and LIM sea ice (Timmermann et al. 2005) are coupled by the OASIS3 coupler (Valcke 2006). This model is very close to the one used in CMIP3 (Dufresne et al. 2005), but with increased horizontal resolution.

- ECHAM5-C is a version of the Max Planck Institute for Meteorology Earth System Model in a low resolution, consisting of the atmospheric component ECHAM5 (Roeckner et al. 2006) including the carbon cycle by the modular land surface scheme JSBACH (Raddatz et al. 2007) and the oceanic component MPI-OM (Marsland et al. 2003) extended by the ocean biochemistry model HAMOCC5 (Maier-Reimer et al. 2005).

- The AOGCM EGMAM (Huebener et al. 2007) is an extended version of ECHO-G (Legutke and Voss 1999) including the atmosphere and land model ECHAM4 (Roeckner et al. 1996) extended to the $0.01 \mathrm{hPa}$ level and the ocean model HOPE-G (Wolff et al. 1997). EGMAM+ is further extended by an updated 3D-ozone forcing and a sulfur aerosol transport scheme. The model employs flux correction for heat and freshwater fluxes, which is constant in time. For sea level changes and oceanic heat uptake the linear trend of the pre-industrial control simulation is subtracted as a drift correction.

- The AOGCM CNRM-CM3.3 is an improved and updated version of CNRM-CM3.1 AR4 model (SalasMélia et al. 2005). It is based on the coupled core formed by the atmosphere model ARPEGE-Climat (Déqué et al. 1994; Royer et al. 2002; Gibelin and Déqué 2003) and the ocean model OPA8.1. ARPEGEClimat includes stratospheric ozone. In the calculation of sea level changes the linear trend of the preindustrial control simulation is subtracted.

- The AOGCM BCM2 (Otterå et al. 2009) is an updated version of BCM (Furevik et al. 2003). The atmospheric component is based on ARPEGE-Climat3 (Déqué et al. 1994) and the oceanic component is MICOM (Bleck and Smith 1990; Bleck et al. 1992).

- The BCM-C model (Tjiputra et al. 2010) is an extension of BCM2. It also includes the Lund-Potsdam-Jena model (LPJ) (Sitch et al. 2003) for terrestrial carbon and the HAMOCC5.1 (Maier-Reimer 1993; Maier-Reimer et al. 2005) for oceanic biochemistry.

More details on the sea ice components included in the coupled models are given in Table 1 . 
Table 1 Overview of sea ice model details and references and number of pairs of simulations used for the analyses

\begin{tabular}{llllll}
\hline Model & Dynamics & $\begin{array}{l}\text { Number of ice } \\
\text { thickness categories }\end{array}$ & $\begin{array}{l}\text { Number of } \\
\text { vertical levels }\end{array}$ & References & $\begin{array}{l}\text { Number of pairs of } \\
\text { simulations in sea } \\
\text { level/sea ice analysis }\end{array}$ \\
\hline BCM2 & EVP & 4 & 4 & Salas-Mélia (2002) & $1 / 1$ \\
BCM-C & VP & 1 & 1 & Drange and Simonsen (1996) & $1 / 1$ \\
CNRM-CM3.3 & EVP & 8 & 10 & Salas-Mélia (2002) & $1 / 1$ \\
ECHAM5-C & VP & 1 & 1 & Marsland et al. (2003) & $3 / 3$ \\
EGMAM+ & VP & 1 & 1 & Wolff et al. (1997) & $1 / 1$ \\
HadCM3C & Ice advected by & 1 & 1 & Gregory and Lowe (2000) & $1 / 1$ \\
& ocean currents & & 1 & McLaren et al. (2006) & $1 / 2$ \\
HadGEM2-AO & EVP & 5 & 2 & Fichefet and Morales-Maqueda (1997) & -13 \\
IPSL-CM4 & VP & 1 & & Fichefet and Morales-Maqueda (1999)
\end{tabular}

Here VP and EVP respectively stand for Viscous-Plastic (Hibler 1979) and Elastic Viscous-Plastic rheologies (Hunke and Dukowicz 1997). In the fourth column, the number of vertical levels concerns only the ice part of sea ice-snow slabs; all models include one layer of snow

\subsection{Climate change scenarios}

For the purpose of analyzing the impact of mitigation on sea ice changes and sea level rise we compare results from simulations using two greenhouse gas concentration pathway scenarios, SRES A1B (Nakicenovic et al. 2000) and E1 (Lowe et al. 2009). The A1B scenario assumes higheconomic growth, strong globalization and rapid technology development without any climate-change mitigation policies, leading to a medium-high emission scenario within the group of SRES scenarios. It was chosen as one of the marker scenarios for the AR4 and therefore model simulations using it have been analyzed extensively.

The E1 scenario was developed with the IMAGE 2.4 Integrated Assessment Model and corresponds to a baseline A1B scenario in terms of demographic, social, economic, technological, and environmental developments. The IMAGE A1B baseline scenario is slightly different from the IPCC A1B scenario (Nakicenovic et al. 2000), since it includes some updates concerning assumptions on population scenarios and economic growth in low-income countries (van Vuuren et al. 2007). In contrast to the A1B baseline scenario, the E1 scenario implies strong mitigation measures such that GHG levels peak at 530 ppmv $\mathrm{CO}_{2^{-}}$ equivalents in 2049 and then gradually decrease to stabilize at 450 ppmv $\mathrm{CO}_{2}$-equivalents in the twenty-second century. The reduction of GHG concentrations in the E1 scenario comes from changes to the energy system, reduction in non- $\mathrm{CO}_{2}$ GHGs, and afforestation.

For the ENSEMBLES S2 experiment (see Johns et al. 2011 for a more detailed description of the experimental setup), the models are forced by time varying GHG concentrations, landuse changes, aerosols, and ozone concentration. The radiative forcing from GHGs is generally lower in the E1 scenario compared to the A1B scenario. In the E1 scenario there is a rapid decrease of the aerosol burden throughout the twentyfirst century, with aerosol burdens almost returning to preindustrial levels by 2100 . By contrast, in the A1B scenario the aerosol burden increases to a peak in 2020 and decreases rapidly thereafter. Johns et al. (2011) show that in some models during the early twenty-first century these two counteracting forcings can lead to warming that is a little stronger under E1 compared to A1B. By the end of the twenty-first century, however, all models show significantly reduced warming under E1 compared with A1B.

\section{Sea level rise}

\subsection{Steric sea level rise}

During the first half of the twenty-first century, the model projections of global-mean steric expansion under the A1B and E1 scenarios are similar (Fig. 1a). A near insensitivity to the scenario for the early part of the century has also been demonstrated in the previous two IPCC assessment reports (Church et al. 2001; Meehl et al. 2007). In the latter part of the twenty-first century, steric expansion is substantially greater under the A1B scenario, and by the end of the century (2080-2099 relative to 1980-1999) the models project a range of expansion of $14-27 \mathrm{~cm}$ under this scenario. These values are within the range of $13-32 \mathrm{~cm}$ given by the AR4 for global-mean thermal expansion under the same scenario for 2090-2099 with respect to 1980-1999 (Meehl et al. 2007). For each individual model the steric expansion is notably reduced under E1, although the 
Fig. 1 a Global annual mean steric sea level rise for A1B (solid lines) and $\mathrm{E} 1$ (dashed lines) (m); b 11-year running trend of global mean steric sea level rise for $\mathrm{A} 1 \mathrm{~B}$ and $\mathrm{E} 1$ $(\mathrm{mm} / \mathrm{a})$
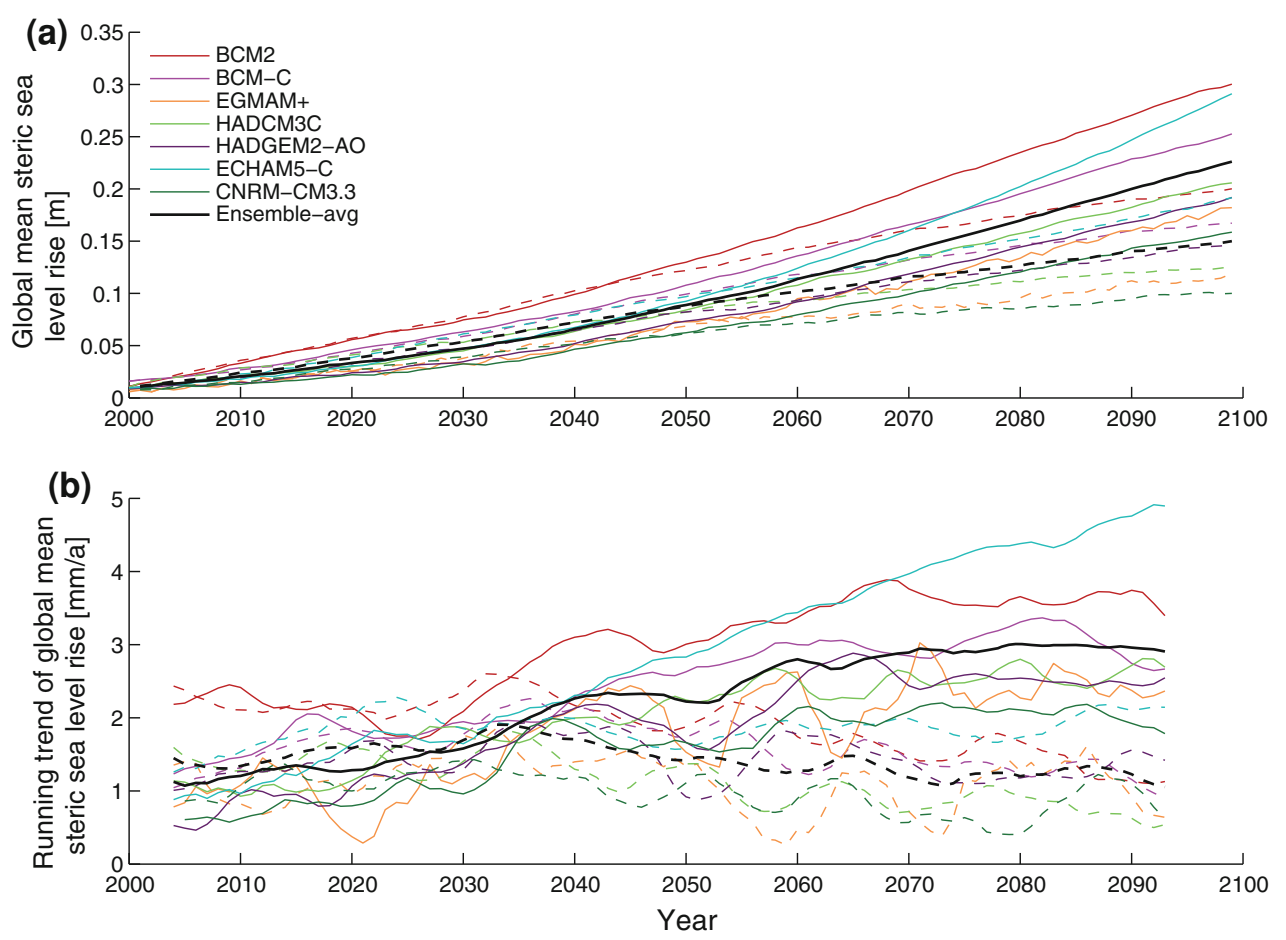

projected inter-model range of 9-19 $\mathrm{cm}$ overlaps with that under A1B. The ensemble mean expansion projections for $\mathrm{A} 1 \mathrm{~B}$ and E1 respectively are 20 and $14 \mathrm{~cm}$, indicating that about $30 \%$ of the expansion could be avoided with mitigation. This percentage, however, varies between the individual models, ranging from 30 to $35 \%$ for most models to about $20 \%$ for HadGEM2-AO. In terms of absolute changes (in meters) the avoided amount of steric expansion is significantly correlated $(\mathrm{R}=0.87)$ with the steric expansion without mitigation, meaning that a model that simulates high steric expansion also shows the largest reduction under mitigation. In terms of relative changes, models with high expansion rates, namely BCM2, BCM-C, and ECHAM5-C, simulate an avoided fraction of about $30 \%$, while models with lower expansion rates, namely CNRM-CM3.3, EGMAM+, and HadCM3C, simulate an avoided fraction of 32-35\%.

The decadal rates of steric expansion over the twenty-first century are always positive, i.e. sea level is rising in each decade in every model (Fig. 1b). At the beginning of the twenty-first century the decadal rates of steric expansion are similar for the two scenarios but vary considerably among the models, ranging from about 0.5 to $2.4 \mathrm{~mm} /$ year under the two scenarios (the observed rate of thermal expansion for 1993-2003 is given by AR4 as $1.6 \pm 0.5 \mathrm{~mm} /$ year). Under A1B there is an increase over the century in the rates of expansion for all models and by the final decade of the twenty-first century the range is $1.8-4.9 \mathrm{~mm} /$ year. Under E1 the rates over the latter part of the century are considerably slower but remain positive with a range of $0.6-2.1 \mathrm{~mm} / \mathrm{year}$, similar to the spread for both scenarios at the beginning of the century. Unlike the amount of expansion itself, where there is a fair amount of overlap between the scenarios even at the end of the century, only the highest projected decadal expansion rate under the E1 scenario (ECHAM5-C) and the lowest rate under the A1B scenario (CNRM-CM3.3) overlap after 2065.

While the rates of sea level rise show considerable interannual to decadal variability, the ensemble mean expansion rates approximately stabilize under the A1B scenario towards the end of the twenty-first century. By contrast the rate of expansion decreases under the E1 scenario. Interestingly, the model with the greatest amount of sea level rise over the twenty-first century appears to have rates of sea level rise under A1B that have stabilized, while the model with the next largest amount of steric expansion across the ensemble has a near linear increasing trend in the rate of expansion over the century, which is still evident at the end of the century (compare lines for models BCM2 and ECHAM5-C in Fig. 1). These two models which show similar sea level rise at 2100 would be likely to show very different amounts of sea level rise into the twenty-second century.

Although the projected increases in steric expansion and in global mean near-surface temperature over the twentyfirst century tend to be higher under A1B than under E1 

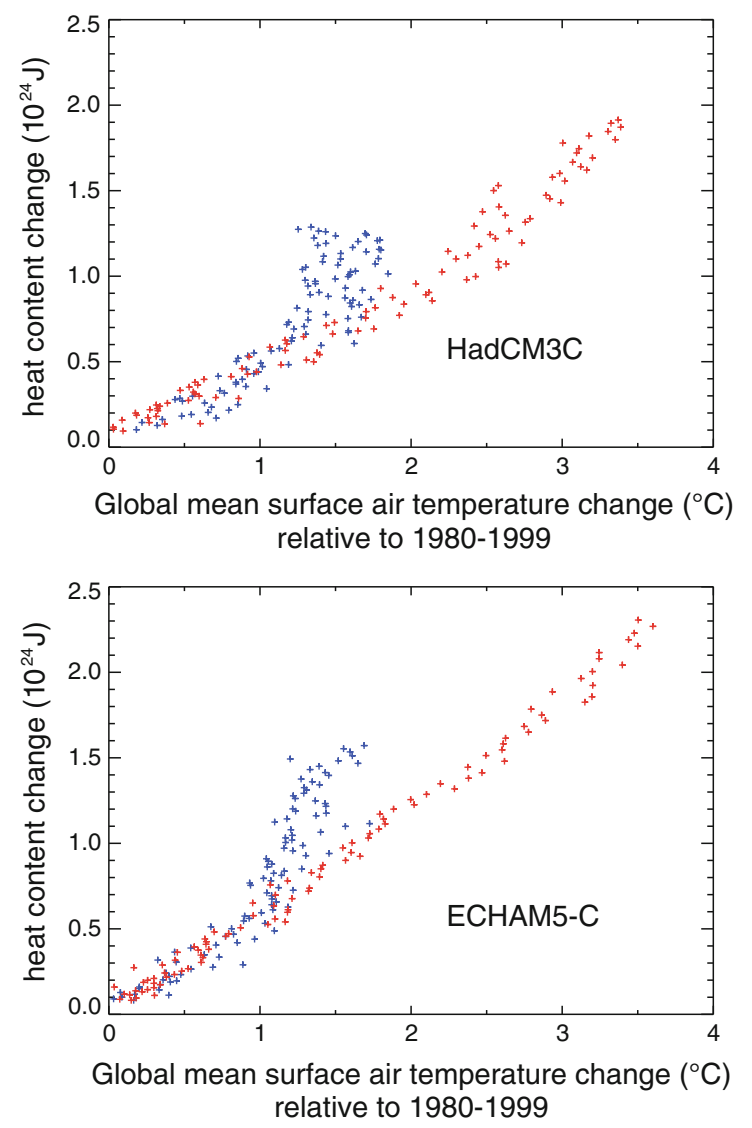

Fig. 2 Relationship between changes in global mean near-surface air temperature and in heat content (both relative to the 1980-1999 mean period) over the twenty-first century for four models under the A1B

(with a linear correlation coefficient between these quantities across both scenarios and all members of the ensemble being 0.68 , which is greater than the $95 \%$ significance level of the student $t$ test), the quantities are not well correlated across the model ensemble for a particular scenario (correlation of 0.35 for $\mathrm{A} 1 \mathrm{~B}$ and 0.53 for $\mathrm{E} 1$, which are both below the $90 \%$ significance level). Globalmean steric expansion depends primarily on heat uptake and on the efficiency with which this heat uptake is translated into expansion of the water column. This does not result in a simple relationship of steric expansion with surface temperature changes across the ensemble.

The relationship of heat content change with surface temperature change, under both the $\mathrm{A} 1 \mathrm{~B}$ and the E1 scenario, is shown for four selected models from the ensemble in Fig. 2. The shape of these scatter-plots is generally similar for each of the models, although it differs markedly between the two scenarios. Pardaens et al. (2011) note that the relationship between heat content change and surface temperature change is near linear in the initial decades as radiative forcing is increased and thermal expansion of the upper ocean dominates. As the heat is subsequently reaches the deeper ocean, there is some deviation from linearity
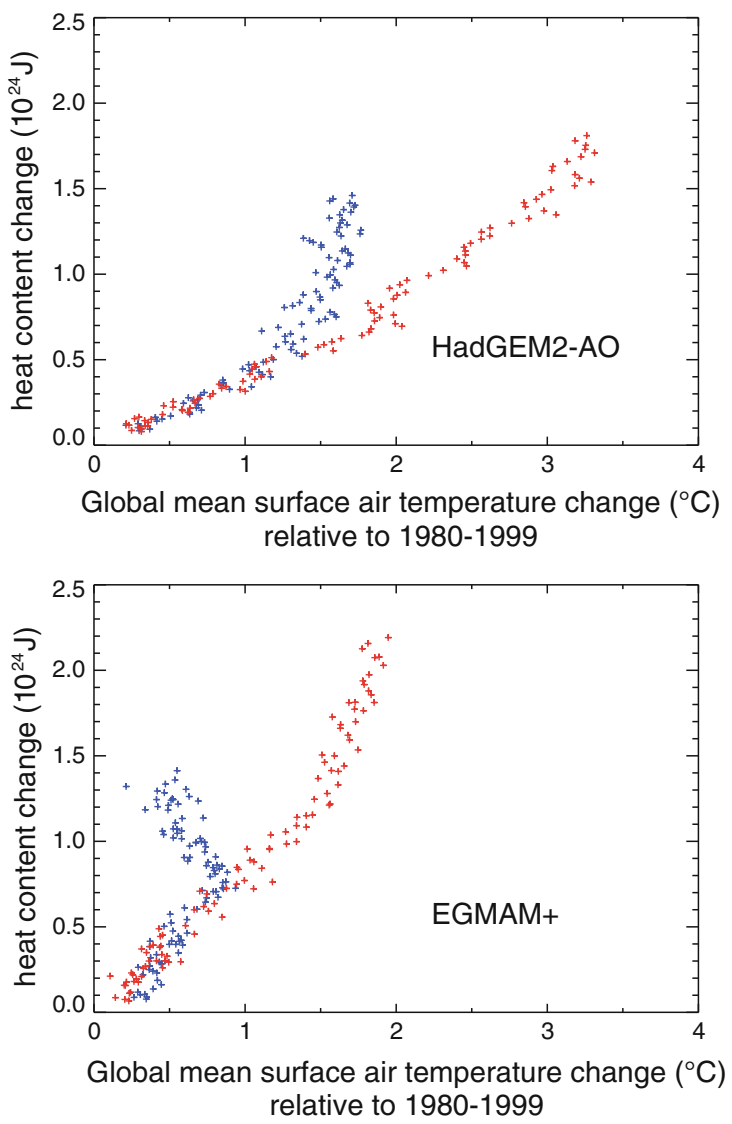

(red crosses) and E1 (blue crosses) scenarios. Each cross represents one annual mean from the 2000 to 2100 period

under the A1B scenario and a much sharper deviation from linearity under E1. In this latter case, surface air temperatures are close to stabilization but there is ongoing expansion of the ocean. This result is consistent with a study by Li et al. (2012), who found that with stabilized greenhouse gas concentrations the deep-ocean warming plays an important role for the global thermosteric sea level change and therefore, in the long term, surface temperature is a poor predictor for steric sea-level. Moreover, the magnitude of the heat content increase over the century shows no obvious correspondence with the magnitude of the near-surface temperature increases. Both the ECHAM5-C and EGMAM+ models, for example, show similar increases in heat content under $\mathrm{A} 1 \mathrm{~B}$, but the increase in surface temperature projected by EGMAM+ over this period is less than $60 \%$ of that for the ECHAM5$\mathrm{C}$ model. For EGMAM+ the near-surface air temperature under E1 shows a reduction towards the latter part of the century, rather than the stabilization given by the other models, but for all models the heat content continues to increase as heat reaches deeper into the ocean and an increasing volume of water expands (see also Meehl et al. 2012). 


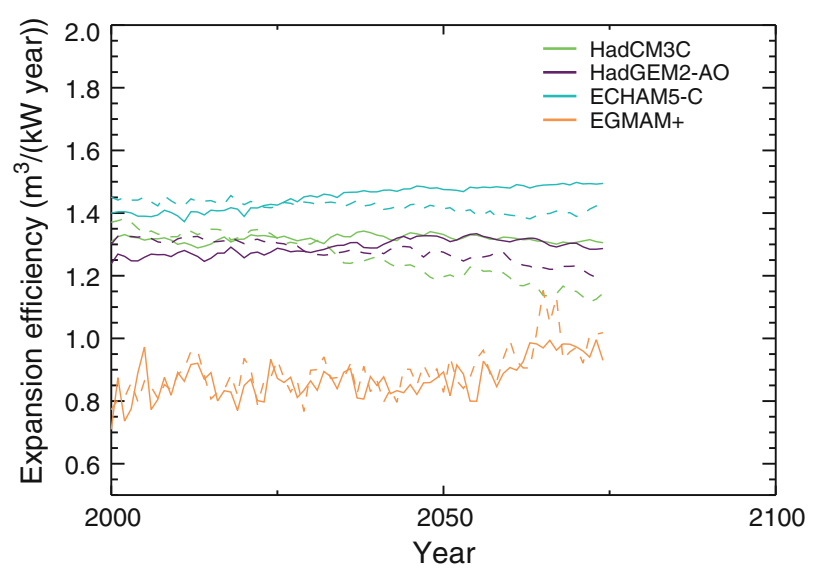

Fig. 3 Expansion efficiency for each of four models under the A1B (solid lines) and E1 (dashed lines) scenarios over the twenty-first century. Values are calculated using averages of the rate of thermal expansion and heat uptake over 50 year periods and allocated to the central time. See text for details

The efficiency with which changes in heat content are translated into steric expansion is an important factor for differences in expansion between models. This "expansion efficiency of heat" is given by the ratio of the rate of thermal expansion (in $\mathrm{mm} / \mathrm{year}$ ) to heat entering the ocean (in $\mathrm{W} / \mathrm{m}^{2}$ ) with these two terms calculated as averages over a particular period (expansion efficiency is not linear with this period). Russell et al. (2000) used expansion efficiency calculated over 50 year intervals as part of their analysis of sea level rise projections under global warming. Here we similarly analyze expansion efficiencies calculated for 50 year intervals and their evolution over the century (Fig. 3). ${ }^{1}$

The expansion efficiency of heat increases with temperature, pressure or salinity. A high expansion efficiency tends to indicate that heat is being distributed into warmer (surface, tropical) water and a low value tends to suggest distribution into colder (deeper, higher latitude) water. Thus, differences in expansion efficiency between models depend on the differing baseline states of the model oceans as well as on the interplay between where heat is added or re-distributed and the subsequent evolving temperature and salinity distributions (any model drift would also play a role).

In the early part of the twenty-first century the expansion efficiencies are similar for the ECHAM5-C, HadCM3C,

\footnotetext{
$\overline{1}$ Time series of expansion efficiency calculated using changes over shorter intervals generally reflect those calculated from 50 year intervals, but show increasing variability. When the system is closer to equilibrium the expansion efficiency is also more prone to noise (absolute changes in the numerator and denominator can be small but give large changes in the expansion efficiency), and prior to 2000 values calculated over 50 year intervals are also subject to greater variability.
}

and HadGEM2-AO models under both scenarios (slightly higher under E1 than under A1B). For these models there is a decreasing trend in expansion efficiency over the century under E1, which is smallest for ECHAM5-C and largest for HadCM3C. After around 2025 expansion efficiency is greater under A1B than E1 for all three of these models, remaining relatively stable for HadCM $3 \mathrm{C}$ and HadGEM2$\mathrm{AO}$ and increasing for ECHAM5-C; this latter model has the highest expansion efficiency values. For a given amount of heat uptake the steric expansion will thus be greatest for this model.

EGMAM+ behaves very differently compared to the three models discussed above: Its expansion efficiency values are notably lower over the full century. The values are similar for both scenarios and they show more interannual to decadal variability. For a given amount of heat uptake, expansion will be lower than for the other models. The similar increases in twenty-first century heat content for EGMAM+ and ECHAM5-C under A1B, which we noted earlier (despite very different increases in global mean surface temperature) thus result in a much greater steric expansion for ECHAM5-C than for EGMAM+.

The trend of decrease in expansion efficiency under mitigation for three of the four models is reminiscent of the decreases seen by Russell et al. (2000) in their greenhouse gas warming experiments. The surface temperatures under E1 for these three models remain relatively stable in the latter parts of the century (Fig. 4) despite the ongoing heat uptake. This result suggests that somewhat deeper colder waters are likely to be the main location of the increase in heat content during this period. The depths at which heat content changes take place (over successive 50 year intervals) was further investigated for the models HadCM3C, HadGEM2-AO, and EGMAM + (results not shown) and support this suggestion. However, our projections also show some rather different behavior to that noted by Russell et al. (2000); for example, the increase in expansion efficiency for ECHAM5-C model under A1B. Surface temperatures continue to increase over the century for all models under A1B. Heat added to warming surface waters under this scenario leads to an increase in expansion efficiency, while heat added to the deeper colder waters leads to a smaller expansion efficiency. This balance is likely to be the main process determining the trend in expansion efficiency (although other factors, such as redistribution between warmer and colder regions of the upper ocean could be important). A full analysis of the reasons for the differences in expansion efficiency is beyond the scope of this study, but our inter-model comparison clearly shows that differences in expansion efficiency as well as in heat uptake can be important in determining the overall contribution of expansion to sea level rise. 


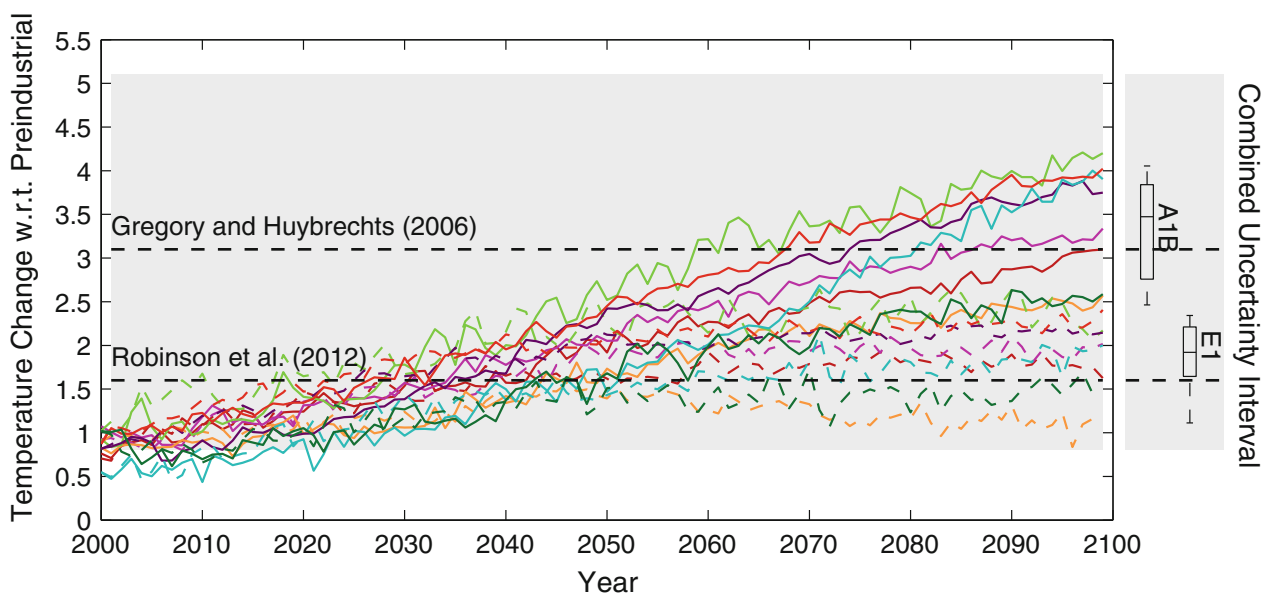

Fig. 4 Global mean near surface temperature change w.r.t. preindustrial. Solid/dashed lines represent the A1B/E1 scenario. The grey area illustrates combined uncertainty range for a threshold for the GIS from Gregory and Huybrechts (2006) and Robinson et al. (2012); the corresponding best estimates are represented by black dashed line.

\subsection{Temperature thresholds for the Greenland ice sheet}

Another important contribution to sea level rise is melting of land-based ice. For example, the elimination of the Greenland ice sheet (GIS) would raise global mean sea level by $7 \mathrm{~m}$ (Meehl et al. 2007). For sustained warmings above a certain threshold, it is likely that the ice sheet would eventually melt completely. Gregory and $\mathrm{Hu}-$ ybrechts (2006) estimated that the threshold at which the net surface mass balance of the GIS becomes negative is given at a global mean near surface warming of $1.9-5.1^{\circ} \mathrm{C}$ (95\% confidence interval) with a best estimate of $3.1{ }^{\circ} \mathrm{C}$ relative to the preindustrial period. Robinson et al. (2012) found that the threshold leading to a monostable essentially ice-free state is in the range of $0.8-3.2^{\circ} \mathrm{C}$ with a best estimate of $1.6^{\circ} \mathrm{C}$.

The global average temperature increases in the models presented in our study have been analyzed in Johns et al. (2011). In summary, while the temperatures are projected to increase throughout the entire twenty-first century in the A1B scenario, they stabilize in the second part of the century in the E1 scenario (Fig. 4). By the end of the century under A1B all models display a temperature increase above the best estimate from Robinson et al. (2012), and more than half of the models display a temperature increase above the best estimate from Gregory and Huybrechts (2006). As intended in the E1 scenario design, the global mean temperature increase by the end of the twenty-first century is about $2{ }^{\circ} \mathrm{C}$ above preindustrial levels. While only one model, namely EGMAM+, shows a temperature increase well below $1.6^{\circ} \mathrm{C}$, none of the models project a temperature increase of more than $3.1^{\circ} \mathrm{C}$. Note that if the full uncertainty range given by Robinson
Box whiskers are shown for the mean near surface temperature increases for the last decade of the twenty-first century. The box represents the 25 th to 75 th percentile, and the whiskers give the full range and the median is displayed as a black line. Colors as in Fig. 1 and red lines for IPSL-CM4

et al. (2012) were considered, most models exceed the threshold early in the twenty-first century (Fig. 4). Still, for reliable estimates, models which include a fully coupled land-ice component would be needed.

\section{Sea ice changes}

In this section, we first present a summary of the statistics of sea ice cover for the recent climate. Then, an analysis of projected sea ice changes is presented based on all participating models. Here, a particular focus will be the avoided fraction of sea ice change in E1. Where more than one realization of a scenario was available the simulated sea ice extent is averaged over the ensemble members so that all models are weighted equally in the analysis.

Following the widely used approach in model studies (e.g. Arzel et al. 2006) and observational studies (e.g. Johannessen et al. 2004), the sea ice extent is defined as the total area of all grid boxes where at least $15 \%$ of the grid box area is covered by sea ice. The model resolutions (which affect the size of the grid boxes) and particular land-sea masks used both affect the calculation of the sea ice extent. As an observational reference, sea ice extent from SSMR data until June 1987, then SSM/I data until 1999 (Fetterer et al. 2002) provided by NSIDC (Boulder, CO, USA) are used.

For the analysis of the spatial patterns of sea ice extent and its projected changes, the simulated sea ice concentrations from the eight models were interpolated to a $1^{\circ} \times 1^{\circ}$ grid (using mean values for the models ECHAM5C, HadGEM2-AO, and IPSL-CM4). The HadISST dataset (Rayner et al. 2003), which is provided on the same grid, is 
Table 2 Sea ice statistics (1980-1999): simulated annual mean sea ice extent and standard deviation of detrended annual mean sea ice extent, and means for March and September $\left(10^{6} \mathrm{~km}^{2}\right)$; model results and the NSIDC observational data set are shown

\begin{tabular}{|c|c|c|c|c|c|c|c|c|}
\hline \multirow[t]{2}{*}{ Model } & \multicolumn{4}{|l|}{ Arctic } & \multicolumn{4}{|l|}{ Antarctic } \\
\hline & Annual mean & SD & Mar mean & Sep mean & Annual mean & SD & Mar mean & Sep mean \\
\hline BCM2 & 11.72 & 0.37 & 15.36 & 6.07 & 1.57 & 0.10 & 0.01 & 3.18 \\
\hline BCM-C & 14.12 & 0.16 & 16.60 & 11.43 & 5.98 & 0.37 & 1.67 & 10.24 \\
\hline EGMAM+ & 13.75 & 0.29 & 18.71 & 8.35 & 11.42 & 0.86 & 2.30 & 21.43 \\
\hline HadCM3C & 11.59 & 0.45 & 16.55 & 5.71 & 14.43 & 0.83 & 4.88 & 24 \\
\hline HadGEM2-AO & 14.50 & 0.21 & 19.46 & 7.05 & 12.76 & 0.54 & 4.45 & 19.93 \\
\hline ECHAM5-C & 12.43 & 0.14 & 16.20 & 8.50 & 15.20 & 0.45 & 8.28 & 23.13 \\
\hline IPSL-CM4 & 11.77 & 0.25 & 17.58 & 5.01 & 12.33 & 0.35 & 1.56 & 23.69 \\
\hline CNRM-CM3.3 & 11.03 & 0.11 & 13.18 & 8.75 & 4.86 & 0.44 & 0.01 & 12.27 \\
\hline Ensemble-avg & 12.61 & 0.08 & 16.70 & 7.61 & 9.82 & 0.11 & 2.89 & 17.23 \\
\hline NSIDC Obs & 12.23 & 0.17 & 15.82 & 7.11 & 11.96 & 0.15 & 4.35 & 18.80 \\
\hline
\end{tabular}

employed as an observational reference. To illustrate the level of agreement between the models percentiles are shown instead of means.

\subsection{Present day climatology}

All models capture the observed annual mean value of the Arctic sea ice extent of $12.23 \times 10^{6} \mathrm{~km}^{2}$ (Fetterer et al. 2002 ) with errors of less than $20 \%$ of the observed value (Table 2) and reproduce the main characteristics of the seasonal cycle of Arctic sea ice (Fig. 5a). Thus, as already shown for the AR4 models (e.g. Arzel et al. 2006; Flato et al. 2004), there is a fairly good agreement between the model simulations and the observations in terms of Arctic sea ice extent. Although the spread of simulated ice edge is large, especially in September (Fig. 6), the median Arctic sea ice extent (50\% contour) for the period 1980-1999 agrees well with the observations (thick magenta line) for both March and September. The evaluation of Arctic sea ice simulations are summarized in a Taylor diagram (Fig. 7a).

By contrast, the simulations of Antarctic sea ice reveal large biases, with the ensemble mean underestimating the observed sea ice extent of $11.96 \times 10^{6} \mathrm{~km}^{2}$ for the period 1980-1999 (Fetterer et al. 2002) by about $18 \%$. Moreover, the ensemble spread itself is greater than the observed value. In the models BCM2, BCM-C, and CNRM-CM3.3 less than half of the observed extent is simulated. The main cause for the underestimation of Antarctic sea ice extent in $\mathrm{BCM} 2$ and BCM-C is excessive mixing between the surface and the deep ocean in the Southern Ocean (Ottera et al. 2009). This excessive mixing erodes the simulated haloclines in these two models and makes it difficult to maintain the fresh and cold surface layers required for wintertime freezing and formation of sea ice. In the
CNRM-CM3.3 model the main reason for the lack of sea ice is the overestimation of incoming short wave solar radiation. This radiative bias causes excessive melting of sea ice and ocean surface temperatures which are too warm, particularly during summer and fall. These warm ocean conditions delay the formation of new sea ice, since freezing is only possible when the mixed layer temperature is close to the freezing point.

While the median September sea ice edge agrees reasonably well with observations, the spatial patterns of Antarctic sea ice (Fig. 8) demonstrate a fairly consistent underestimation of sea ice concentration at the end of the Southern Hemisphere summer by most models. The evaluation of Antarctic sea ice simulations is summarized in a Taylor diagram (Fig. 7b). Owing to the large biases in the present day simulations of the Antarctic sea ice patterns, we will not discuss spatial patterns of projected changes for the Antarctic sea ice.

\subsection{Projected sea ice changes}

As a response to rising greenhouse gas concentrations and the corresponding temperature increase, sea ice extent is expected to decrease in both hemispheres. In the following sections, we analyze the changes in Arctic and Antarctic sea ice changes individually for late summer (Arctic: September; Antarctic: March) and late winter (Arctic: March, Antarctic: September).

\subsubsection{Arctic sea ice changes}

In the multi-model ensemble mean, Arctic sea ice extent is projected to decrease during the first half of the twenty-first century in both scenarios (Fig. 9). In the E1 scenario the rate of reduction in sea ice extent decelerates throughout 
Fig. 5 Seasonal cycle of Arctic (a) and Antarctic (b) sea ice extent for the 1980-1999 climatology simulated by the models, ensemble mean (dashed black line) and NSIDC observations (solid black line) $\left(10^{6} \mathrm{~km}^{2}\right)$
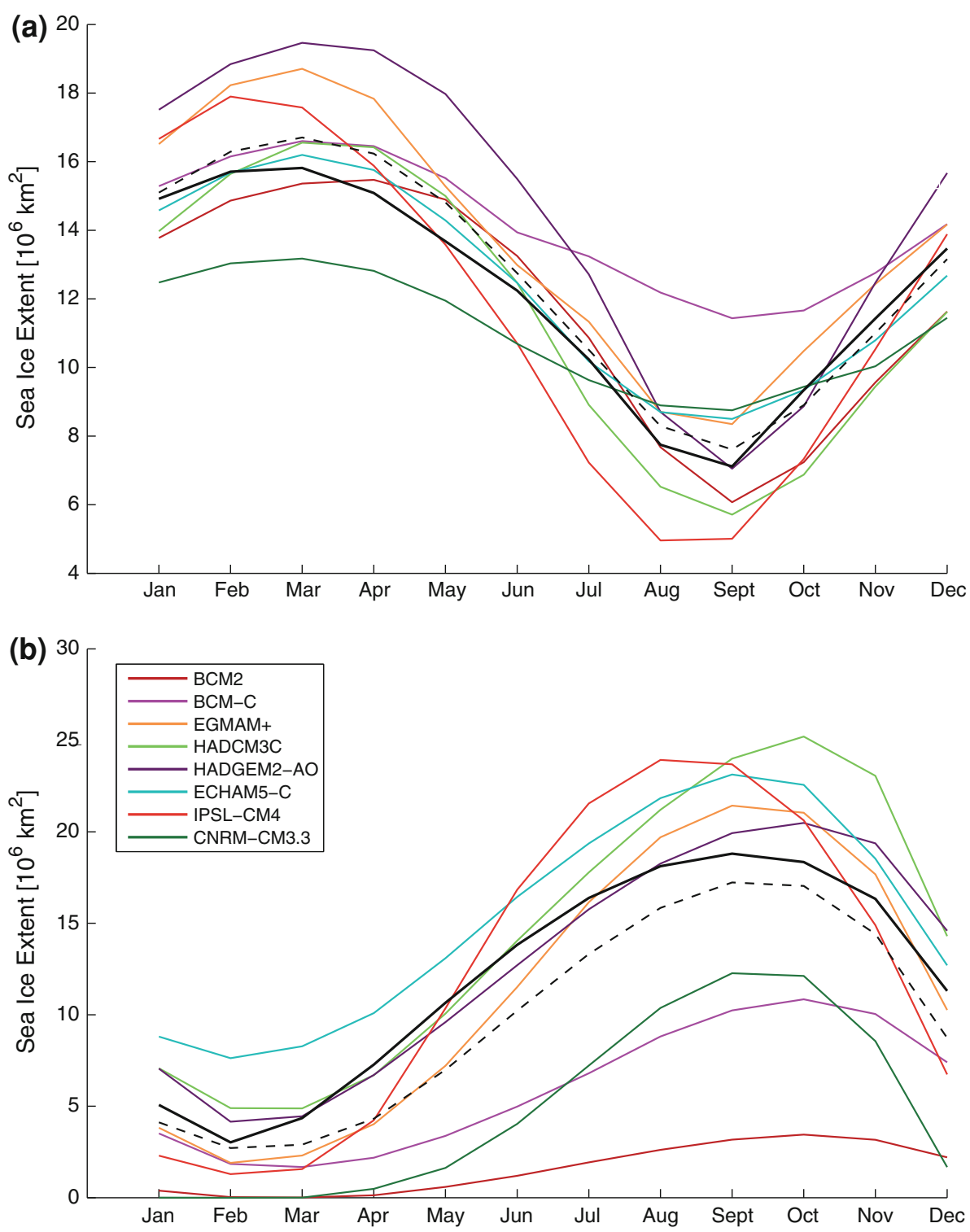

the twenty-first century in both seasons (Fig. 9b, d, f, h). By contrast, in the A1B scenario, the rate of reduction of March extent remains at a similar level until the end of the century and the median sea ice edge is projected to shift polewards (Fig. 6d). A deceleration of the reduction is found for the September sea ice extent, especially during the second half of this century (Fig. 9a, c, e, g). The reason for this deceleration is an ice free Arctic, i.e. a sea ice extent of less than $1 \times 10^{6} \mathrm{~km}^{2}$, as simulated by several models.

While most models display a rather slow decrease of the September sea ice extent during the first half of the twentyfirst century, in BCM2 the sea ice extent decreases rather rapidly during the first two decades of the century in both scenarios. Under the A1B scenario, BCM2 simulates an ice free Arctic for September starting around 2045, IPSL-CM4 around 2050, HadCM3C around 2060, and HadGEM2-AO and ECHAM5-C around 2080 (see also Fig. 6c for the spatial distributions of Arctic sea ice for the end of the twenty-first century). By contrast, three models, namely EGMAM+, BCM-C, and CNRM-CM3.3, do not simulate an ice free Arctic under the A1B scenario, with an extent ranging from less than $3 \times 10^{6} \mathrm{~km}^{2}$ (EGMAM+) to more than $8.5 \times 10^{6} \mathrm{~km}^{2}$ (BCM-C) model; however, the BCM$\mathrm{C}$ model overestimates the present day Arctic sea ice extent, namely over the Barents Sea. By contrast, under the E1 scenario there are only two models simulating a September extent less than $1 \times 10^{6} \mathrm{~km}^{2}$, namely BCM2 and IPSL-CM4.

The multi-model mean September sea ice extent stabilizes at about $2.2 \times 10^{6} \mathrm{~km}^{2}$ in the $\mathrm{A} 1 \mathrm{~B}$ scenario and $4.4 \times 10^{6} \mathrm{~km}^{2}$ in the E1 scenario. Thus, according to the model projections, a reduction corresponding to about $35 \%$ of the present day September sea ice extent will be 
Fig. 6 Arctic range of sea ice extent in the model simulations. Shading indicates the percentage of models that have a sea ice fraction of more than $15 \%$ of the grid box in September (left) and March (right) for 1980-1999 (a, b); 2080-2099 in the A1B scenario $(\mathbf{c}, \mathbf{d})$, and the E1 scenario (e, f). The observed sea ice edge (thick magenta line) is based on the HadISST dataset (Rayner et al. 2003) (a) ENS percent 20C 1980_1999 S

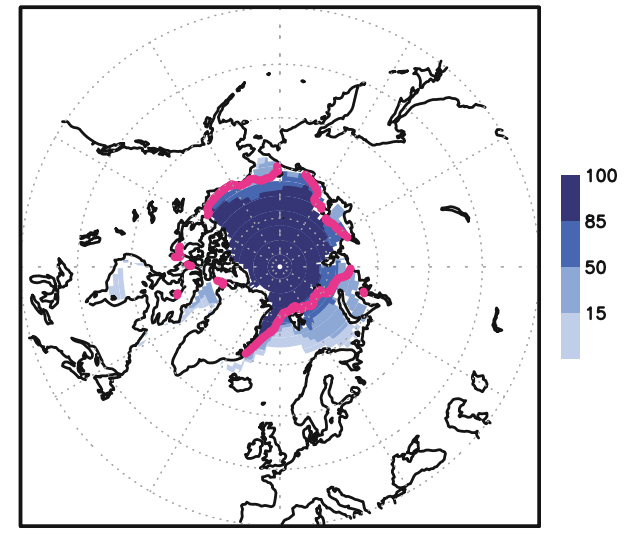

(c) ENS percent A1B 2080_2099 S

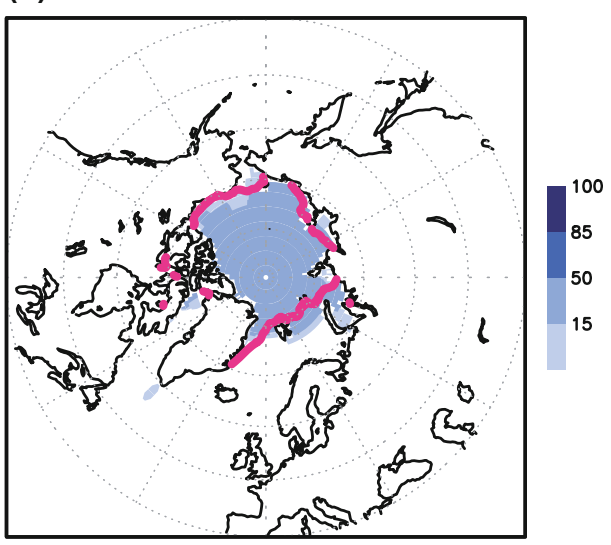

(e) ENS percent E1 2080_2099 S

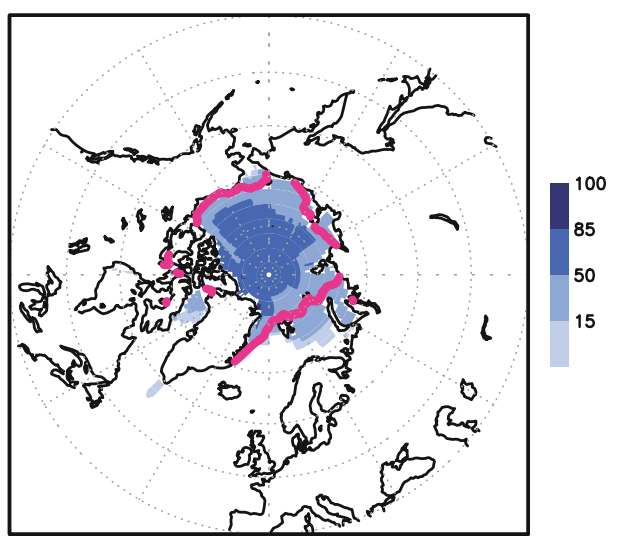

(b) ENS percent 20C 1980_1999 M

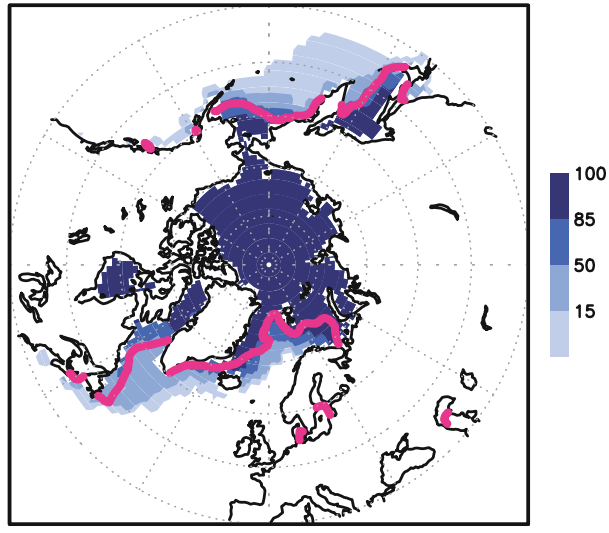

(d) ENS percent A1B 2080_2099 M

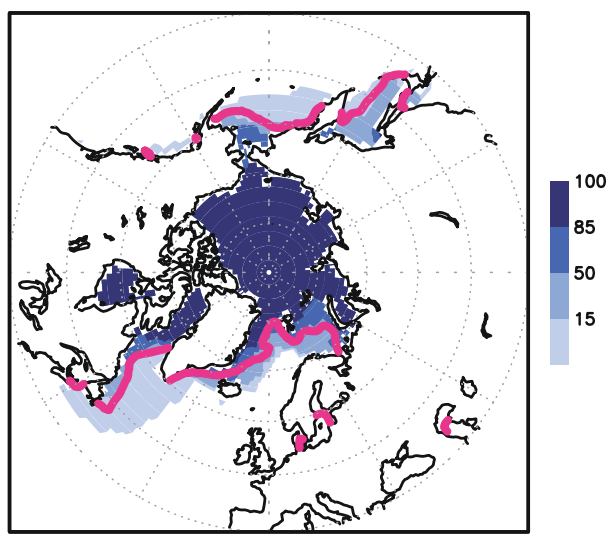

(f) ENS percent E1 2080_2099 M

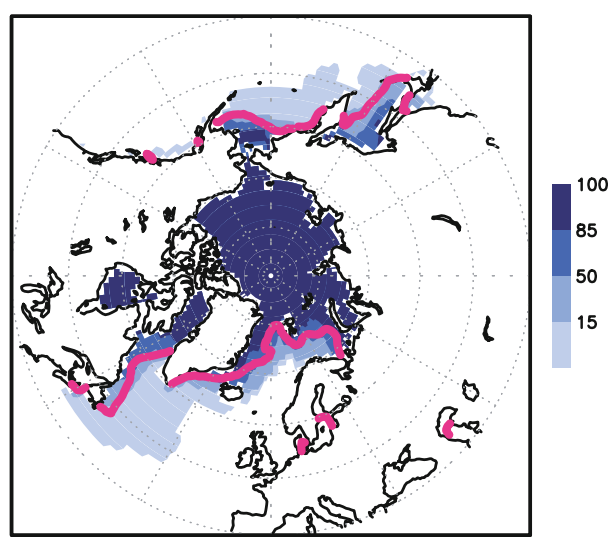

avoided in the E1 scenario (Fig. 10b). The remaining ice cover is restricted to the central Arctic Ocean and does not reach Eurasia or Alaska (Fig. 6e). The avoided fraction is somewhat less than estimated by Washington et al. (2009) for their mitigation scenario.

While most models reveal a potential to avoid sea ice reductions, the CNRM-CM3.3 model shows a slight increase in Arctic sea ice extent in March for both scenarios (Figs. 9a, b, 10a). This is due to a marked increase of the amount of sea ice in the northern Labrador Sea, itself explained by the shutdown of ocean convection owing to warmer conditions in this area. Since the surface warming is more pronounced in the A1B than in the E1 scenario, it turns out that there is more sea ice in the Labrador Sea by the end of the twenty-first century in the A1B than in the E1 simulation. A full study of this phenomenon, as found in an A1B simulation performed with a previous version of CNRM-CM (AR4 version), can be found in Guemas and 


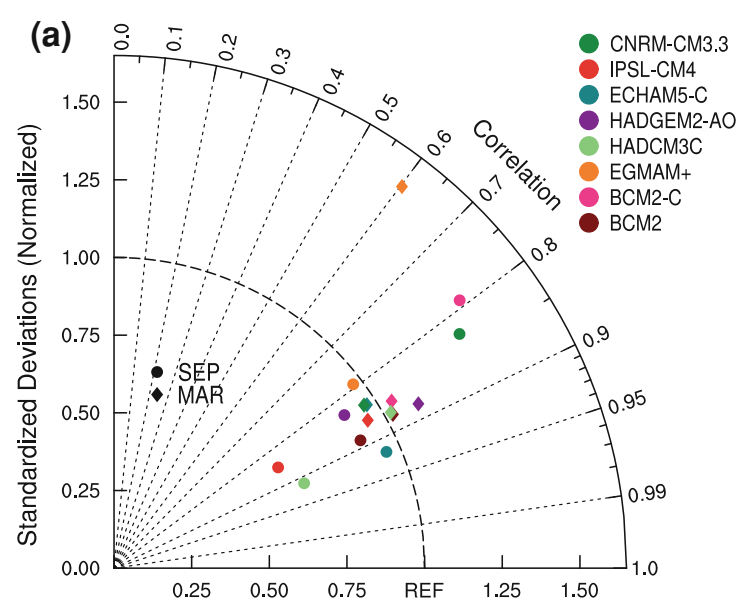

Fig. 7 Taylor diagrams (Taylor 2001) showing correlation and normalized standard deviation (1980-1999) for the Arctic (a) and the Antarctic (b) patterns of the sea ice fraction (where sea ice covers

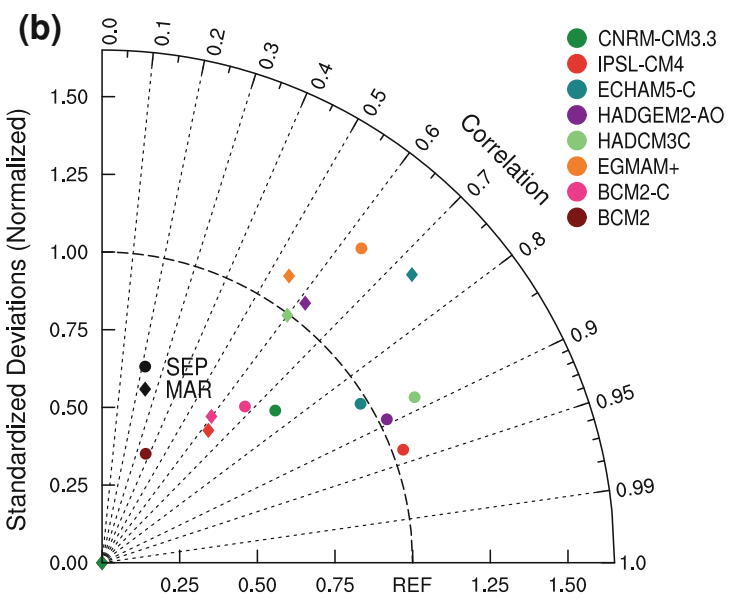

more than $15 \%$ of the grid cell) in September (circles) and March (diamonds). Reference data is HadISST (Rayner et al. 2003) from 1980 to 1999
Fig. 8 As Fig. 6a, b but for Antarctic

\section{(a) ENS percent 20C 1980_1999 S}

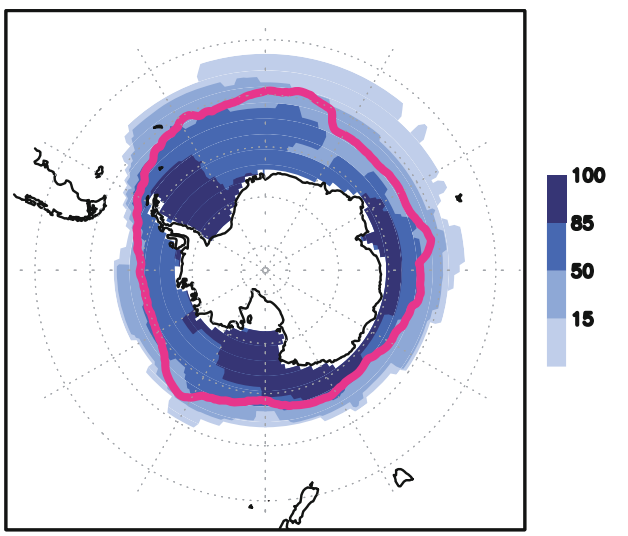

(b) ENS percent 20C 1980_1999 M

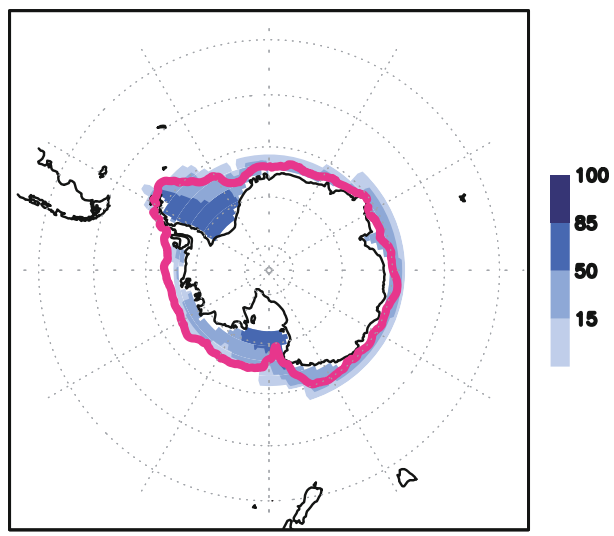

Salas-Mèlia (2008). Likewise, March sea ice extent in EGMAM+ displays large variability on decadal timescales (Fig. 9a, b), which is related to strong variability in the Labrador Sea, with an average reduction somewhat weaker than the ensemble mean (Fig. 10a).

The different behavior for the two seasons indicates that the decrease in multiyear sea ice is stronger than the reductions of seasonally covered areas. Consistent with the results of the AR4 for the $\mathrm{A} 1 \mathrm{~B}, \mathrm{~A} 2$, and $\mathrm{B} 1$ scenarios (Zhang and Walsh 2006), this amplification of the seasonal cycle is less pronounced in the E1 scenario compared to the A1B scenario. The multi-model ensemble mean extent in September is approximately $16 \%$ of the simulated March extent in the A1B scenario and $30 \%$ in E1 (Table 2) by the end of the twenty-first century. Among others reasons, such as differences in the radiation budget, the different behavior for March and September is related to the ice thickness. In most of the models the relative Arctic sea ice volume change during March is about two to three times the relative fraction of the sea ice extent change (Table 3), as indicated in previous studies (Gregory et al. 2002; Arzel et al. 2006); in contrast, sea ice volume and extent changes are about equal during September. This feature is explained by a negative growth-thickness feedback (Bitz and Roe 2004). Since the sea ice growth rates depend on the reciprocal of the sea ice thickness, when ice thins the growth rates increase. The relationship between the reduction in sea ice volume per reduction in sea ice area is, however, not linear, since for larger reductions in area the volume loss is not so great (Gregory et al. 2002). Since Arctic September sea ice is already very thin at the beginning of the twenty-first century, the growth-thickness feedback is rather weak.

Evidently, in E1 the fraction of volume loss per loss in sea ice extent is larger than in A1B, which can also be related to the weaker growth-thickness feedback in the A1B scenario. This finding is in accordance with earlier studies (e.g. Gregory et al. 2002). Owing to a slight increase in sea ice extent in March in the models CNRMCM3.3 in both scenarios and in EGMAM+ in the E1 
Fig. 9 Multi-model simulated anomalies in sea ice extent for the A1B scenario (left column) and the E1 scenario (right column) for upper two rows (a-d): Arctic March (a, b) September (c, d); lower two rows (e-h): same but for the Antarctic, ensemble mean anomalies depicted in thick black lines; sea ice extent defined as the total area where sea ice concentration exceeds $15 \%$; anomalies relative to the period 1980-2000; the ensemble mean 1980-1999 extent of the respective hemispheres and month are depicted in the subfigure titles in the right column
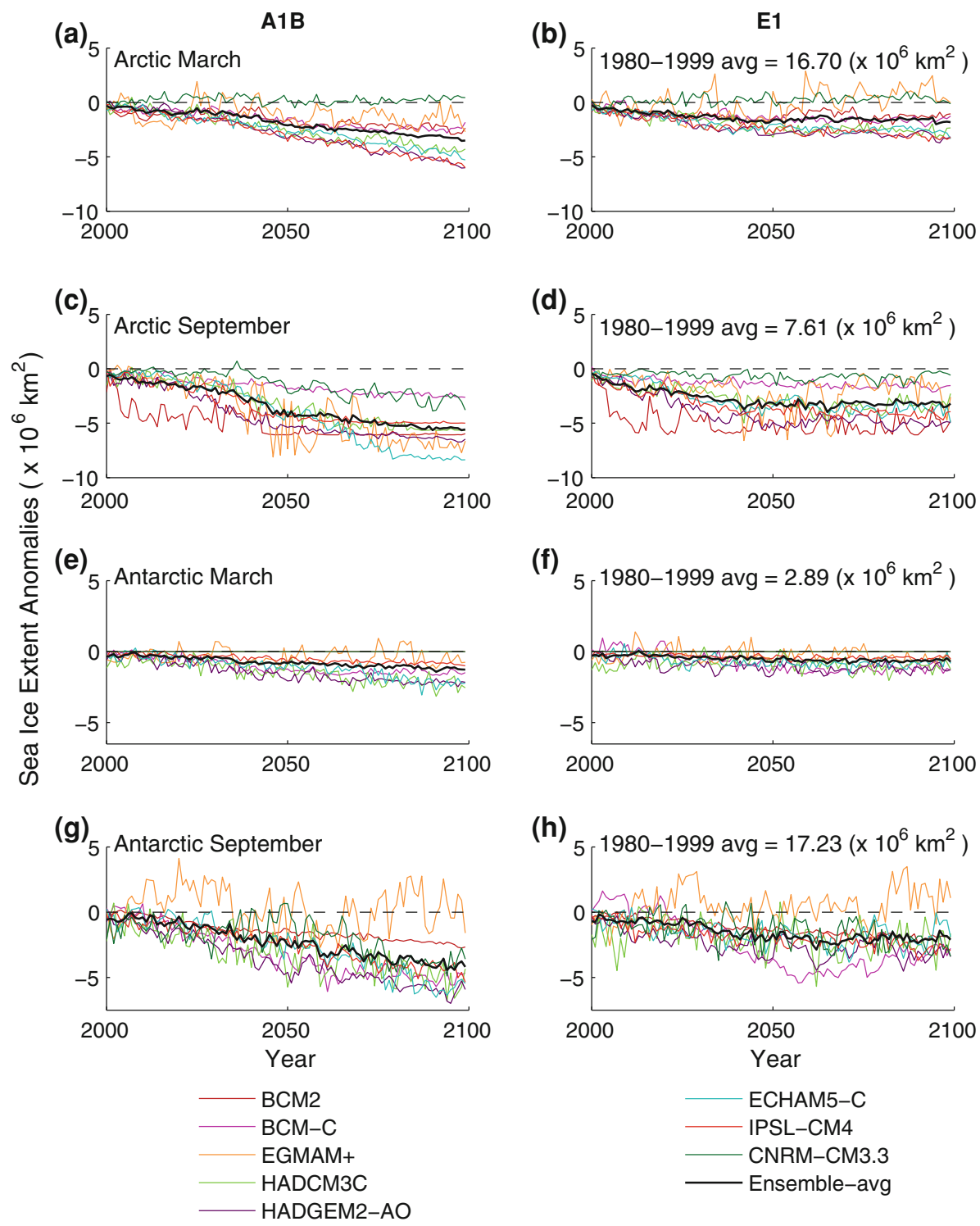

(h)

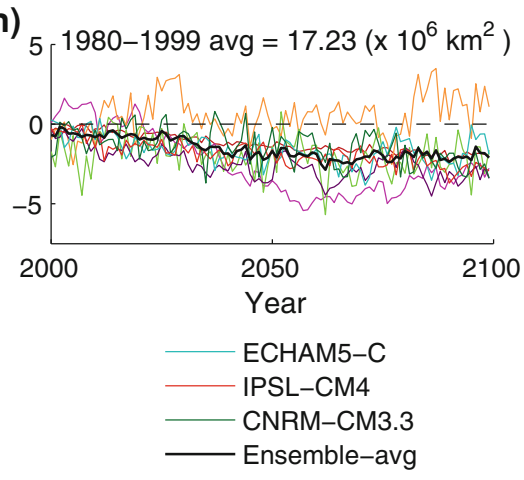

scenario (see Sect. 4.2.1), the relationship is actually negative, i.e. the Northern Hemispheric sea ice volume decreases while the extent actually increases slightly.

While model differences for Arctic March sea ice extent in the A1B scenario are larger than the interannual to decadal variability found in most models (Fig. 9a), the simulated reductions of late winter sea ice extent is more consistent between the models in the E1 scenario. The multi-model spread of the simulated September sea ice extent by the end of the twenty-first century in the A1B scenario is of the same order as the reduction of the ice extent itself.

Some of the uncertainty associated with the sea ice changes may be explained by the many different global mean temperature responses of the models. In addition, the rate of annual Arctic sea ice extent decline compared to present day levels per $1{ }^{\circ} \mathrm{C}$ warming varies significantly among the models. In the CNRM-CM3.3 model the rate is about $4 \% /{ }^{\circ} \mathrm{C}$, in the IPSL-CM4 it is about $16 \% /{ }^{\circ} \mathrm{C}$ (Fig. 11). The differences in the sensitivity can be explained by two factors, Arctic polar amplification and local sea ice sensitivity (Mahlstein and Knutti 2012). These factors are linked, since sea ice is known to play a crucial role in the amplification of warming due to the ice-albedo feedback (see Mahlstein and Knutti 2012 for a more detailed discussion).

Differences in the sensitivity of sea ice to temperature changes between the A1B and E1 scenarios are small (Fig. 11), but the relationship varies for the different seasons. In March, differences between the scenarios are very small (not shown), indicating a close linear relationship between temperature changes and sea ice changes. In September the sensitivity depends on how much ice is available for melt (not shown). The simulated Arctic sea 

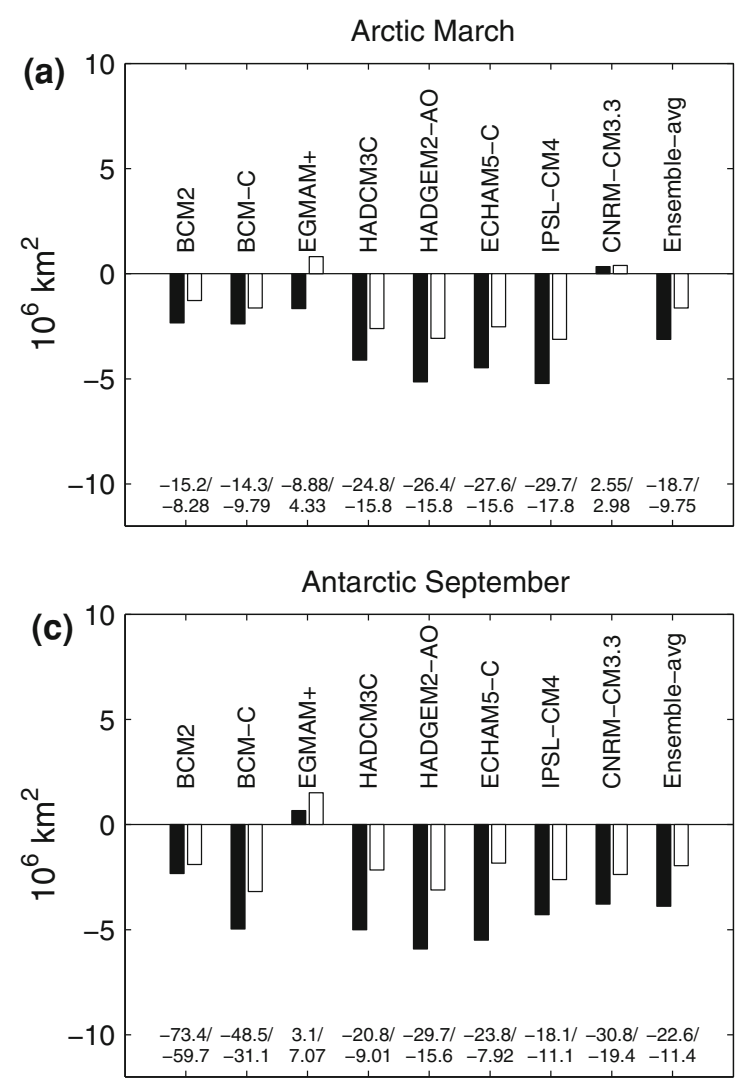

Fig. 10 Changes of the sea ice extent (2080-2099 relative to 1980-1999). Black bars depict A1B changes, white bars E1changes $\left(10^{6} \mathrm{~km}^{2}\right)$; relative changes of $\mathrm{A} 1 \mathrm{~B} / \mathrm{E} 1$ are given below the bars $(\%)$.

Table 3 Ratio of sea ice volume change to sea ice extent change in fractions of initial state

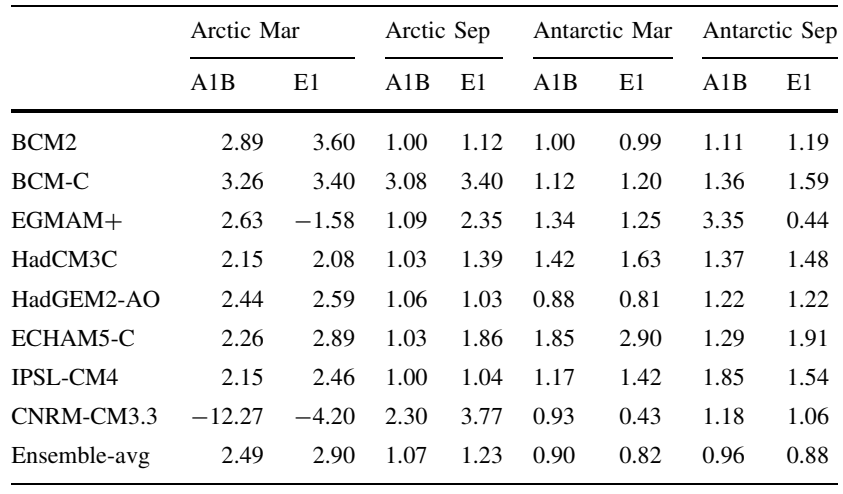

Mar March, Sep September

ice decline per degree of warming for most models is stronger in the E1 scenario than in the A1B scenario, when there is still a large amount of sea ice in the beginning of the twenty-first century. As soon as the Arctic becomes ice free or almost ice free, the relationship between temperature changes and sea ice changes is markedly non-linear (e.g. Mahlstein and Knutti 2012; Ridley et al. 2008). Obviously, once the Arctic is ice free, no more changes
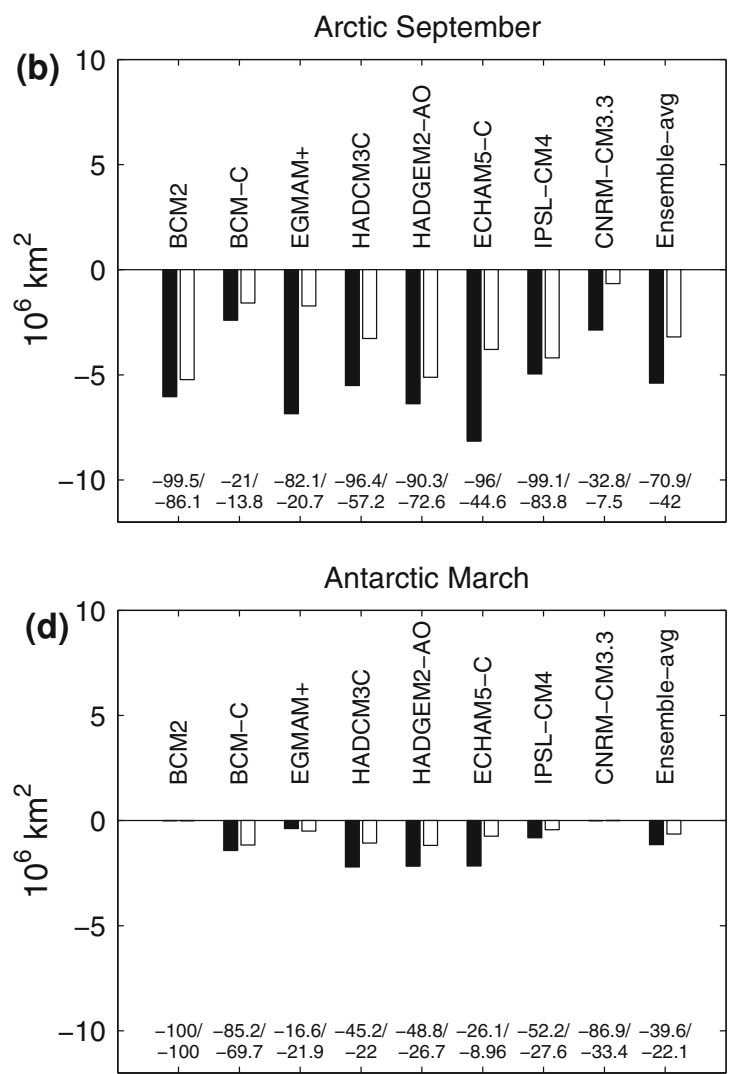

a, b Arctic; c, d Antarctic; a, c end of freezing season (March for Arctic, September for Antarctic); b, d end of melting season (September for Antarctic, March for Arctic)

will occur, even if the temperatures rise. If the Arctic is almost ice free, in a few models some ice always remains, even if the temperatures increase further (see also Wang and Overland 2009). This result is explained by two processes: (1) the maximum ice thickness decreases more slowly due to the growth-thickness feedback (Bitz and Roe 2004), and (2) the snow cover on multi-year ice insulates the ice from the atmosphere (Notz 2009).

While September sea ice reduction under the E1 scenario is related to the present day ice cover (correlation coefficient $\mathrm{R}=0.83$ ), under the A1B scenario where reductions close to $100 \%$ are simulated such a relationship does not exist. In fact, out of the 5 models that simulate an ice free Arctic during the summer within the twenty-first century, those models with less than observed present day summer sea ice extent, namely BCM2, IPSL-CM4, and HadCM3C, produce an ice free Arctic earlier than the models with similar to observed or overestimated present day summer sea ice extent, namely HadGEM2-AO and ECHAM5-C. This is in line with the hypothesis that excessively small ice cover, as is the case during late summer, will respond more sensitively to radiative forcing (e.g. Zhang and Walsh 2006). Therefore, initial biases in Arctic summer ice cover are likely to be an important 

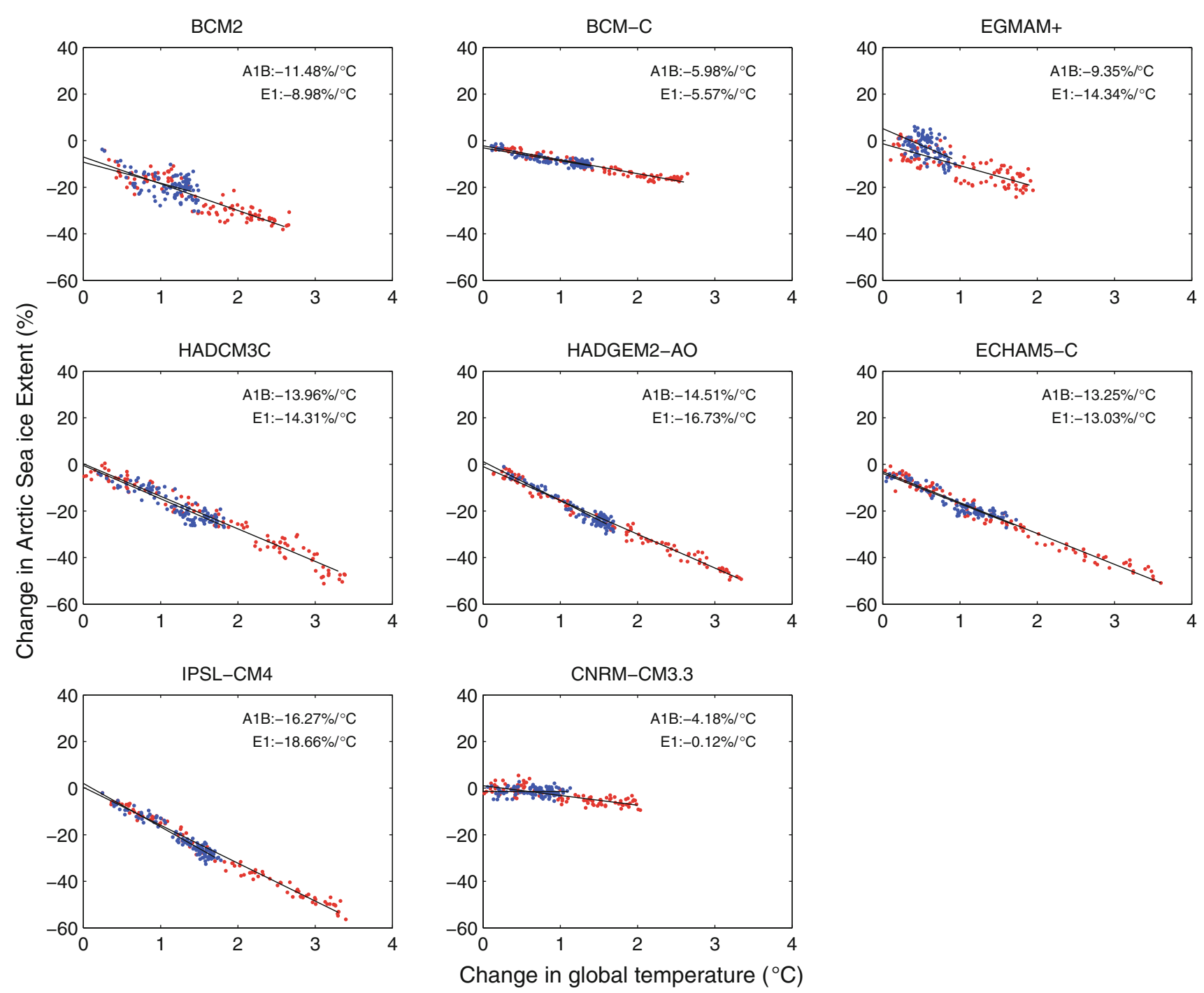

Fig. 11 The relationship between global mean near surface air temperature rise and Arctic annual mean sea ice extent with respect to the present day state (cf. Ridley et al. 2008, Fig. 4). The red dots represent model simulations of the A1B scenario, the blue dots the E1

factor for the simulation of future changes in mitigation scenarios that could prevent an ice-free Arctic. However, under both scenarios there is no significant relationship during March.

The avoided reduction of September Arctic ice extent, i.e. the difference between sea ice extent in A1B and E1 at the end of the twenty-first century, is not significantly related to the initial state of the ice cover. This result indicates that the inter-model spread of the avoided reduction is mainly explained by the processes examined above and is not caused by initial biases in the Arctic sea ice extent or thickness. By contrast, the projected difference of the final sea ice extent in March between the A1B and E1 scenarios significantly correlates with the initial extent $(\mathrm{R}=-0.69 ;>90 \%$ significance level $)$. Note that in scenario. Each dot represents one annual mean from the 2000 to 2100 period. The sensitivities of sea ice changes to temperature changes from linear regression are displayed in the upper right hand corner

terms of the avoided fraction relative to the present day sea ice extent, the correlation coefficient with the initial extent shows a similar relationship, but it is not significant $(\mathrm{R}=-0.5)$. This means that a model that simulates a large initial Arctic sea ice extent in March tends to produce a larger difference between the A1B and E1 scenarios by the end of the twenty-first century.

\subsubsection{Antarctic sea ice changes}

For both seasons the ensemble mean suggests a reduction of Antarctic sea ice extent during the twenty-first century. During the first half of this century the reduction in both scenarios is of the same magnitude (Fig. 9e-h). Afterwards, sea ice extent stabilizes in the E1 scenario, while it 
is further reduced in the A1B scenario. By the end of the twenty-first century (2080-2099) the extent in the A1B scenario is reduced by about $23 \%$ in September and about $39 \%$ in March relative to present day (1980-1999). In the E1 scenario the reduction of extent is only about $11 \%$ for September and $22 \%$ for March. Note that in contrast to relative changes the absolute reduction of sea ice extent is more pronounced during the Southern Hemispheric winter for most models. In contrast to the Arctic, where the amplification of the seasonal cycle is stronger in the A1B scenario, in the Southern Hemisphere the amplitude of the seasonal cycle is similar under both scenarios. However, the spread of changes in sea ice extent within the ensemble is especially large, with a magnitude similar to the ensemble mean change, especially in the E1 scenario.

Differing from the changes in the Arctic, the Antarctic sea ice volume change per sea ice extent change ratio is less than one, i.e. sea ice extent decreases are stronger than the volume decreases (Table 3). Only some models, namely BCM-C, HadCM3C, and ECHAM5-C, indicate a larger Antarctic sea ice volume loss per loss in sea ice extent in the E1 scenario compared to the A1B scenario for both seasons, again highlighting less confidence in sea ice changes in Antarctica than the Arctic.

In contrast to the projections of Arctic sea ice extent, the projected Antarctic sea ice extent reductions are highly dependent on the initial sea ice extent in the models. The correlation coefficient between the relative reduction of sea ice extent and the initial extent is in the range of 0.64-0.89 depending on season and scenario. Here, in line with the ice-albedo feedback, a model with a large sea ice extent for present-day climate tends to simulate a weak reduction in a future climate under increasing GHG concentrations. This relationship is stronger during Southern Hemispheric winter. However, it should be pointed out that the correlation is based on a sample of only eight models. Three of them, namely BCM2, BCM-C, and CNRM-CM3.3, largely underestimate present day sea ice extent and consistently simulate the strongest relative reductions during the twenty-first century. The projected changes from these three models dominate the correlation coefficient, whereas the relationship is not as strong for the other models. In terms of the potential to avoid reductions in the sea ice extent, models that simulate a larger present day sea ice extent during Southern Hemispheric winter tend to simulate less potential for avoiding reductions in the E1 scenario compared to the A1B scenario $(\mathrm{R}=0.4)$. For the Antarctic summer extent such a relationship does not exist.

Consistent with the pronounced relationship between the initial state and the projected changes during the twentyfirst century, the dependency of the Antarctic sea ice extent on Southern Hemispheric temperature change is not as strong as shown for the Northern Hemisphere. Therefore, the correlation coefficients for the linear regression between Antarctic sea ice changes and warming vary considerably among the models, ranging from 0.09 to 0.93 . In models with a close linear relationship, namely HadCM3C, HadGEM2-AO, ECHAM5-C, and IPSL-CM4, the sensitivity is in the range of $9-15 \%$ decrease in sea ice extent per degree warming.

Inter-hemispheric differences in the evolution of the sea ice in the twenty-first century are evident in the results presented above. To a certain extent these differences can be attributed to the land-sea distribution. The Arctic sea ice extent is partly limited by land area, while sea ice extent in the Southern Ocean is not constrained in such a way. Therefore, Eisenman et al. (2011) attribute inter-hemispheric differences in the model projections to the land-sea geometry, suggesting that simulated sea ice changes are consistent with sea ice retreat being fastest in winter in the absence of landmasses. Likewise, Notz and Marotzke (2012) conclude that sea ice changes in the Arctic are mainly driven by greenhouse gas forcing, while Antarctic sea ice changes are primarily governed by sea ice dynamics.

\section{Discussion and conclusions}

In this study projected changes in sea level and sea ice extent in an aggressive mitigation scenario, E1 designed to limit global warming to $2{ }^{\circ} \mathrm{C}$ and a scenario with no mitigation (A1B) are investigated employing a multi-model approach. The fraction of climate change impact that could be avoided is calculated, as has been done in previous studies. In contrast to these previous studies, however, by presenting results from a multi-model ensemble, estimates of the uncertainty are included and possible reasons for the uncertainty are proposed.

In agreement with previous studies using different scenarios (e.g., Church et al. 2001; Meehl et al. 2007) ocean expansion is independent of the scenario during the first half of the twenty-first century. Even under the mitigation scenario expansion is still increasing at the end of the twenty-first century, albeit at a reduced rate compared to that under A1B (see also Meehl et al. 2012). For a particular scenario, however, steric expansion across the ensemble is not well correlated with near surface air temperature changes. Instead, the model spread in projected twenty-first century expansion is substantially affected by differences in both expansion efficiency and heat uptake. The tendency for a decreasing trend in expansion efficiency under the E1 scenario appears to be linked to a transfer of the dominant location of heat uptake from the warmer upper part of the water column to somewhat deeper colder waters. 
The avoided steric expansion under E1 for the twentyfirst century has a spread across the ensemble of 20-35\% of that under the A1B scenario, with ensemble mean expansion of $20 \mathrm{~cm}$ under the A1B scenario and $14 \mathrm{~cm}$ under the E1 scenario. Larger (smaller) amounts of avoided expansion (in meters; not in terms of percentage) across the ensemble are related to larger (smaller) amounts of expansion without mitigation. The ensemble mean avoided expansion is very similar to that found by Washington et al. (2009) in their comparison of business-as-usual and mitigation projections with the CCSM3 coupled climate model, although their scenarios were different to those used here and similar to that found by Yin (2012) in the CMIP5 models, who compared projections using the RCP2.6 and the RCP4.5 scenarios. The twenty-first century pathway of greenhouse gas concentrations will strongly affect sea level commitment beyond the scenario period (Meehl et al. 2006) so that, while around a third of the expansion may be avoided over the twenty-first century, mitigation within the twenty-first century is likely to give substantial further benefits over subsequent centuries.

In this study we have focused on the potential effects of a business-as-usual and a mitigation scenario on the global mean steric expansion component of sea level rise. The net melt of glaciers, ice caps and ice sheets will also contribute to sea level rise with a contribution that may be a notable fraction of the total (Meehl et al. 2007). Reliable conclusions, regarding whether sustained warming above a deglaciation threshold for the Greenland ice sheet may be avoided with the mitigation efforts assumed in the E1 scenario, cannot be drawn without the inclusion of a coupled land-ice model. Moreover, in the longer term, if some parts of the Greenland ice sheet were eliminated, a new equilibrium of this ice sheet may be possible (Ridley et al. 2010; Robinson et al. 2012).

The upper limit for the contribution of glaciers and ice caps outside Greenland and Antarctica can be given by the total ice volume available for melt. It is estimated to be less than $0.4 \mathrm{~m}$ sea level equivalent (Steffen et al. 2010 and references therein) and thus, in the longer term its contribution to sea level rise will diminish. In addition, the extraction of groundwater globally could be an important factor to consider in terms of adaptation and mitigation strategies. About $13 \%$ of the total sea level rise from 2000 to 2008 can be attributed to groundwater depletion (Konikow 2011) and by 2050 the total rise from anthropogenic terrestrial contributions, i.e. groundwater depletion minus dam impoundment, is estimated to be $3.1 \mathrm{~cm}$ (Wada et al. 2012).

Projected changes of sea ice in the A1B and the E1 scenarios have been presented and evaluated in terms of possible dependency on the initial state and temperature changes. As shown for the AR4 models (Arzel et al. 2006; Flato et al. 2004), present day sea ice extent in the Arctic is simulated reasonably well by the models both in terms of annual mean extent and the seasonal cycle. The models' performance in simulating the annual mean sea ice extent and the amplitude of the seasonal cycle in the Antarctic is worse than for the Arctic. Biases in the present day Antarctic sea ice extent are explained by several processes that are related to the oceanic circulation and the radiative budget. The dominating processes differ among the models and need to be assessed more thoroughly in further studies (see also Parkinson et al. 2006).

The Arctic sea ice extent is projected to decrease in the twenty-first century in most models in both scenarios, resulting in a poleward shift of the sea ice edge. The decrease in summer extent is stronger than the annual decrease, indicating an amplification of the seasonal cycle in both scenarios. Consistent with Wang and Overland (2009), Wang and Overland (2012) and Stroeve et al. (2012), the period where an ice free Arctic during September is established varies considerably among the models used in this study. However, our results suggest that under mitigation an ice free Arctic during summer may be avoided and a reduction corresponding to $35 \%$ of the present day extent for September is projected to be avoided in the E1 scenario.

As also pointed out by Zhang and Walsh (2006), we find some indications of a robust relationship between the initial sea ice area and sea ice reduction, since excessively small ice cover responds more sensitively to radiative warming. However, the simulated feedbacks related to the heat and freshwater budgets in the different models may vary considerably. Furthermore, in line with Holland and Bitz (2003) and Mahlstein and Knutti (2012), a strong correlation between the temperature response and the reduction of the sea ice extent in the Arctic is found.

Consistent with the large ensemble spread in present day sea ice extent in the Antarctic, projections for the twentyfirst century reveal considerable uncertainty. In the present study, projections of sea ice extent changes are strongly correlated with the initial ice extent. It is therefore crucial to reduce the model deficiencies that produce the present day biases in Antarctic sea ice extent, since they affect the projected changes. Goosse et al. (2009) concluded that a delicate balance between several processes results in either decreasing or increasing Antarctic sea ice extent and extrapolation of the observed changes for future or past conditions should be considered hazardous. Further research is needed to evaluate the models' ability to simulate the complicated interactions between the thermodynamic response to the radiative forcing, changes in wind stress, related to changes in the atmospheric circulation and oceanic stratification and heat transport.

In light of the aim to avoid "dangerous interference" with the climate system by limiting global warming to 
$2{ }^{\circ} \mathrm{C}$, we conclude that although in the majority of the models the projections suggest that an ice free Arctic in September can be avoided, an ice free Arctic is possible during summer even if global warming is limited to $2{ }^{\circ} \mathrm{C}$. Regardless of mitigation measures, some sea level rise during the twenty-first century and beyond is inevitable. Therefore, in addition to mitigation efforts to limit sea level rise in the twenty-first and subsequent centuries, adaptation measures are likely to be needed in the twenty-first century.

Acknowledgments We gratefully acknowledge the ENSEMBLES project, funded by the European Commission's 6th Framework Program (FP6) through contract GOCE-CT-2003-505539. Anne Pardaens and Jason Lowe were also supported by the Joint DECC/Defra Met Office Hadley Centre Climate Programme (GA01101). We thank two anonymous reviewers for their very helpful suggestions and Larry Gates for his very helpful comments.

Open Access This article is distributed under the terms of the Creative Commons Attribution License which permits any use, distribution, and reproduction in any medium, provided the original author(s) and the source are credited.

\section{References}

Arzel O, Fichefet T, Goose H (2006) Sea ice evolution over the 20th and 21 st centuries as simulated by current AOGCMs. Ocean Model 12:401-415

Bitz CM, Roe GH (2004) A mechanism for the high rate of sea ice thinning in the Arctic Ocean. J Clim 17:3623-3631

Bleck R, Smith LT (1990) A wind-driven isopycnic coordinate model of the North and equatorial Atlantic Ocean. 1: model development and supporting experiments. J Geophys Res 95(C3):3273-3285

Bleck R, Rooth C, Hu D, Smith LT (1992) Salinity-driven thermocline transients in a wind- and thermohaline-forced isopycnic coordinate model of the North Atlantic. J Phys Oceanogr 22:1486-1505

Church JA, Gregory JM, Huybrechts P, Kuhn M, Lambeck K, Nhuan MT, Qin D, Woodworth PL (2001) Changes in sea level. In: Houghton JT, Ding Y, Griggs DJ, Noguer M, van der Linden PJ, Dai X, Maskell K, Johnson CA (eds) Climate change 2001: the scientific basis. Cambridge University Press, Cambridge

Clarke LE, Edmonds JA, Jacoby HD, Pitcher HM, Reilly JM, Richels RG (2007) Scenarios of greenhouse gas emissions and atmospheric concentrations. Syn Assess Prod 2.1a, Department of Energy, Washington, DC, $154 \mathrm{pp}$. Available at http://www. climatescience.gov/Library/sap/sap2-1/default.php

Collins M, Booth BBB, Bhaskaran B, Harris GR, Murphy JM, Sexton DMH, Webb MJ (2011a) Climate model errors, feedbacks and forcings: a comparison of perturbed physics and multi-model ensembles. Clim Dyn 36(9-10):1737-1766. doi:10.1007/s00382010-0808-0

Collins WJ, Bellouin N, Doutriaux-Boucher M, Gedney N, Halloran $\mathrm{P}$, Hinton T, Hughes J, Jones CD, Joshi M, Liddicoat S, Martin G, O’Connor F, Rae J, Senior C, Sitch S, Totterdell I, Wiltshire A, Woodward S, Reichler T, Kim J (2011b) Development and evaluation of an earth-system model-HadGEM2. Geosci Model Dev 4(4):1051-1075. doi:10.5194/gmd-4-1051-2011

Cox PM (2001) Description of the 'TRIFFID' dynamic global vegetation model. Met Office Hadley Centre technical note no. 24, Met Office, Exeter
Déqué M, Dreveton C, Braun A, Cariolle D (1994) The ARPEGE/IFS atmosphere model: a contribution to the French community climate modelling. Clim Dyn 10:249-266

Drange H, Simonsen K (1996) Formulation of air-sea fluxes in the ESOP2 Version of MICOM, technical report 125. Nansen Environmental and Remote Sensing Center, Norway

Dufresne J-L, Quaas J, Boucher O, Denvil F, Fairhead L (2005) Contrasts in the effects on climate of anthropogenic sulfate aerosols between the 20th and the 21st century. Geophys Res Lett 32:L21703. doi:10.1029/2005GL023619

Eisenman I, Schneider T, Battisti DS, Bitz CM (2011) Consistent changes in the sea ice seasonal cycle in response to global warming. J Clim 24:5325-5335. doi:10.1175/2011JCLI4051.1

Essery RLH, Best MJ, Betts RA, Cox PM, Taylor CM (2003) Explicit representation of subgrid heterogeneity in a GCM land surface scheme. J Hydrometeorol 4:530-543

Fetterer F, Knowles K, Meier W, Savoie M (2002, updated 2009) Sea ice index. Digital media. National Snow and Ice Data Center, Boulder

Fichefet T, Morales-Maqueda AM (1997) Sensitivity of a global sea ice model to the treatment of ice thermodynamics and dynamics. J Geophys Res 102(6):12609-12646

Fichefet T, Morales-Maqueda AM (1999) Modelling the influence of snow accumulation and snow-ice formation on the seasonal cycle of the Antarctic sea-ice cover. Clim Dyn 15(4):251-268

Flato GM, The Participating CMIP Modelling Groups (2004) Sea-ice and its response to $\mathrm{CO}_{2}$ forcing as simulated by global climate models. Clim Dyn 23:229-241

Furevik T, Bentsen M, Drange $H$, Kindem IKT, Kvamsto NG, Sorteberg A (2003) Description and evaluation of the Bergen climate model: ARPEGE coupled with MICOM. Clim Dyn 21:27-51

Gibelin AL, Déqué M (2003) Anthropogenic climate change over the Mediterranean region simulated by a global variable resolution model. Clim Dyn 20:327-339

Goosse H, Lefebvre W, de Montety A, Crespin E, Orsi AH (2009) Consistent past half-century trends in the atmosphere, the sea ice and the ocean at high southern latitudes. Clim Dyn 33:999-1016. doi:10.1007/s00382-008-0500-9

Gordon C, Cooper C, Senior CA, Banks H, Gregory JM, Johns TC, Mitchell JFB, Wood RA (2000) The simulation of SST, sea ice extents and ocean heat transports in a version of the Hadley Centre coupled model without flux adjustments. Clim Dyn 16:147-168

Gregory JM, Huybrechts P (2006) Ice-sheet contributions to future sea level change. Philos Trans R Soc Lond A 364:1709-1731

Gregory JM, Lowe JA (2000) Predictions of global and regional sea level rise using AOGCMs with and without flux adjustment. Geophys Res Lett 27:3069-3072

Gregory JM, Scott PA, Cresswell DJ, Rayner NA, Gordon C, Sexton DMH (2002) Recent and future changes in Arctic sea ice simulated by the HadCM3 AOGCM. Geophys Res Lett 29(24):2175. doi:10.1029/2201GL014575

Guemas V, Salas-Mèlia D (2008) Simulation of the Atlantic Meridional Overturning Circulation in an atmosphere-ocean global coupled model, part II: weakening in a climate change experiment: a feedback mechanism. Clim Dyn 30(7-8):831-844. doi:10.1007/s00382-007-0328-8

Hansen J, Sato M (2004) Greenhouse gas growth rates. Proc Natl Acad Sci 101:16109-16114

Hansen J et al (2007) Dangerous human-made interference with climate: a GISS model study. Atmos Chem Phys 7:2287-2312

Hewitt CD, Griggs DJ (2004) Ensembles-based predictions of climate changes and their impacts. EOS Trans AGU 85:566

Hibler WD (1979) A dynamic thermodynamic sea ice model. J Phys Oceanogr 9:815-846 
Holland MM, Bitz CM (2003) Polar amplification of climate change in coupled models. Clim Dyn 21:221-232

Hourdin F, Musat I, Bony S, Braconnot P, Codron F, Dufresne JL, Fairhead L, Filiberti MA, Friedlingstein P, Grandpeix JY, Krinner G, Levan P, Li ZX, Lott F (2006) The LMDZ4 general circulation model: climate performance and sensitivity to parameterized physics with emphasis on tropical convection. Clim Dyn 27:787-813

Huebener H, Cubasch U, Langematz U, Spangehl T, Niehörster F, Fast I, Kunze M (2007) Ensemble climate simulations using a fully coupled ocean-troposphere-stratosphere general circulation model. Philos Trans R Soc Lond A 365:2089-2101

Hunke EC, Dukowicz JK (1997) An elastic-viscous-plastic model for sea ice dynamics. J Phys Oceanogr 27:1849-1867

Johannessen OM et al (2004) Arctic climate change: observed and modelled temperature and sea-ice variability. Tellus 56A:328341

Johns TC, Durman CF, Banks HT, Roberts MJ, McLaren AJ, Ridley JK, Senior CA, Williams KD, Jones A, Rickard GJ, Cusack S, Ingram WJ, Crucifix M, Sexton DMH, Joshi MM, Dong BW, Spencer H, Hill RSR, Gregory JM, Keen AB, Pardaens AK, Lowe JA, Bodas-Salcedo A, Stark S, Searl Y (2006) The new Hadley Centre Climate Model (HadGEM1): evaluation of coupled simulations. J Clim 19:1327-1353

Johns TC, Royer J-F, Höschel I, Huebener H, Roeckner E, Manzini E, May W, Dufresne J-L, Otterå OH, van Vuuren DP, Salas y Melia D, Giorgetta MA, Denvil S, Yang S, Fogli PG, Körper J, Tjiputra JF, Stehfest E, Hewitt CD (2011) Climate change under aggressive mitigation: the ENSEMBLES multi-model experiment. Clim Dyn 37:1975-2003. doi:10.1007/s00382-011-1005-5

Konikow LF (2011) Contribution of global groundwater depletion since 1900 to sea-level rise. Geophys Res Lett 38:L17401. doi: 10.1029/2011GL048604

Krinner G, Viovy N, de Noblet-Ducoudré N, Ogée J, Polcher J, Friedlingstein P, Ciais P, Sitch S, Prentice IC (2005) A dynamic global vegetation model for studies of the coupled atmospherebiosphere system. Global Biogeochem Cycles 19:GB1015. doi: 10.1029/2003GB002199

Legutke S, Voss R (1999) The Hamburg atmosphere-ocean coupled climate circulation model ECHO-G. DKRZ technical report 18. Deutsches Klimarechenzentrum, Hamburg

Li C, von Storch J-S, Marotzke J (2012) Deep-ocean heat uptake and equilibrium climate response. Clim Dyn. doi: 10.1007/s00382-012-1350-z

Lowe JA, Gregory JM, Ridley J, Huybrechts P, Nicholls RJ, Collins M (2006) The role of sea-level rise and the Greenland ice sheet in dangerous climate change: implications for the stabilisation of climate. In: Schnellnhuber HJ, Cramer W, Nakicenovic N, Wigley $\mathrm{T}$, Yohe $\mathrm{G}$ (eds) Avoiding dangerous climate change. Cambridge University Press, New York, pp 29-36

Lowe JA, Hewitt CD, van Vuuren DP, Johns TC, Stehfest E, Royer JF, van der Linden PJ (2009) New study for climate modeling, analyses, and scenarios. EOS Trans AGU 90:181-182

Madec G, Delecluse P, Imbard I, Levy C (1999) OPA 8.1 ocean general circulation model reference manual. Note du Pôle de modélisation no. 11, Inst. Pierre-Simon Laplace (IPSL), France, $91 \mathrm{p}$

Mahlstein I, Knutti R (2012) September Arctic sea ice predicted to disappear near $2^{\circ} \mathrm{C}$ global warming above present. J Geophys Res 117:D06104. doi:10.1029/2011JD016709

Maier-Reimer E (1993) Geochemical cycles in an ocean general circulation model. Preindustrial tracer distribution. Glob Biogeochem Cycles 7:645-677

Maier-Reimer E, Kriest I, Segschneider J, Wetzel P (2005) The Hamburg ocean carbon cycle model HAMOCC 5.1 - technical description release 1.1. Reports on earth system science 14,
ISSN 1614-1199. Available from Max Planck Institute for Meteorology, Hamburg, 50 p. http://www.mpimet.mpg.de

Marsland SJ, Haak H, Jungclaus JH, Latif M, Röske F (2003) The Max-Planck-Institute global ocean/sea ice model with orthogonal curvilinear coordinates. Ocean Model 5:91-127

Marti O, Braconnot P, Dufresne J-L, Bellier J, Benshila R, Bony S, Brockmann P, Cadule P, Caubel A, Codron F, de Noblet N, Denvil S, Fairhead L, Fichefet T, Foujols M-A, Friedlingstein P, Goosse H, Grandpeix J-Y, Guilyardi E, Hourdin F, Krinner G, Lévy C, Madec G, Mignot J, Musat I, Swingedouw D, Talandier C (2010) Key features of the IPSL ocean atmosphere model and its sensitivity to atmospheric resolution. Clim Dyn 34:1-26. doi: 10.1007/s00382-009-0640-6

May W (2008) Climatic changes associated with a global $" 2^{\circ} \mathrm{C}$ stabilization" scenario simulated by the ECHAM5/MPI-OM coupled climate model. Clim Dyn 31:283-313

McLaren AJ et al (2006) Evaluation of the sea ice simulation in a new coupled atmosphere-ocean climate model (HadGEM1). J Geophys Res 111:C12014. doi:10.1029/2005JC003033

Meehl GA, Washington WM, Santer BD, Collins WD, Arblaster JM, Hu A, Lawrence DM, Teng H, Buya LE, Strand WG (2006) Climate change projections for the twenty-first century and climate commitment in the CCSM3. J Clim 19:2597-2616

Meehl GA et al (2007) Global climate projections. In: Solomon S, Qin D, Manning M, Chen Z, Marquis M, Averyt KB, Tignor M, Miller HL (eds) Climate change 2007: the physical science basis. Cambridge University Press, Cambridge, pp 747-845

Meehl GA, Hu A, Tebaldi C, Arblaster JM, Washington WM, Teng H, Sanderson BM, Ault T, Strand WG, White JB (2012) Relative outcomes of climate change mitigation related to global temperature versus sea-level rise. Nat Clim Chang 2:576-580

Nakicenovic NJ et al (2000) IPCC special report on emission scenarios. Cambridge University Press, Cambridge

Nicholls RJ, Lowe JA (2004) Benefits of mitigation of climate change for coastal areas. Glob Environ Chang 14:229-244

Nicholls RJ et al (2007) Coastal systems and low-lying areas. In: Climate change 2007: impacts. adaptation and vulnerability. Cambridge University Press, pp 315-356

Notz D (2009) The future of ice sheets and sea ice: between reversible retreat and unstoppable loss. Proc Natl Acad Sci USA 106(49):20590-20595. doi:10.1073/pnas.0902356106

Notz D, Marotzke J (2012) Observations reveal external driver for Arctic sea-ice retreat. Geophys Res Lett 39:L08502. doi: 10.1029/2012GL051094

Otterå OH, Bentsen M, Bethke I, Kvamstø NG (2009) Simulated preindustrial climate in Bergen Climate Model (version 2): model description and large-scale circulation features. Geosci Model Dev 2:197-212

Palmer RJ, Totterdell IJ (2001) Production and export in a global ocean ecosystem model. Deep Sea Res 48:1169-1198

Pardaens AK, Lowe JA, Brown S, Nicholls RJ, de Gusmão D (2011) Sea-level rise and impacts projections under a future scenario with large greenhouse gas reductions. Geophys Res Lett 38:L12604. doi:10.1029/2011GL047678

Parkinson CL, Vinnikov KY, Cavalieri DJ (2006) Evaluation of the simulation of the annual cycle of Arctic and Antarctic sea ice coverages by 11 major global climate models. J Geophys Res 111:C07012. doi:10.1029/2005JC003408

Raddatz TJ, Reick CH, Knorr W, Kattge J, Roeckner E, Schnur R, Schnitzler KG, Wetzel P, Jungclaus J (2007) Will the tropical land biosphere dominate the climate-carbon cycle feedback during the twenty-first century? Clim Dyn 29:565-574

Rayner NA, Parker DE, Horton EB, Folland CK, Alexander LV, Rowell DP, Kent EC, Kaplan A (2003) Global analyses of sea surface temperature, sea ice an night marine air temperature since the late nineteenth century. J Geophys Res 108:D144407 
Ridley J, Lowe J, Simonin D (2008) The demise of Arctic sea ice during stabilisation at high greenhouse gas concentrations. Clim Dyn 30:333-341

Ridley J, Gregory JM, Huybrechts P, Lowe J (2010) Thresholds for irreversible decline of the Greenland ice sheet. Clim Dyn 35:1049-1057. doi:10.1007/s00382-009-0646-0

Robinson A, Calov R, Ganopolski A (2012) Multistability and critical thresholds of the Greenland ice sheet. Nat Clim Chang 2:429-432. doi:10.1038/nclimate1449

Roeckner E, Arpe K, Bengtsson L, Christoph M, Claussen M, Dümenil L, Esch M, Giorgetta M, Schlese U, Schulzweida U (1996) The atmospheric general circulation model ECHAM4: model description and simulation of present-day climate. Max Planck Institut für Meteorologie, report no. 218, Hamburg

Roeckner E, Brokopf R, Esch M, Giorgetta M, Hagemann S, Kornblueh L, Manzini E, Schlese U, Schulzweida U (2006) Sensitivity of simulated climate to horizontal and vertical resolution in the ECHAM5 atmosphere model. J Clim 19:3771-3791

Royer JF, Cariolle D, Chauvin F, Déqué M, Douville H, Hu RM, Planton S, Rascol A, Ricard JL, Salas y Mélia D, Sevault F, Simon P, Somot S, Tyteca S, Terray L, Valcke S (2002) Simulation des changements climatiques au cours du 21-ème siècle incluant l'ozone stratosphérique (simulation of climate changes during the 21-st century including stratospheric ozone). C R Geosci 334:147-154

Russell GL, Gornitz V, Miller JR (2000) Regional sea level changes projected by the NASA/GISS atmosphere-ocean model. Clim Dyn 16:789-797

Salas-Mélia D (2002) A global coupled sea ice-ocean model. Ocean Model 4:137-172

Salas-Mélia D, Chauvin F, Déqué M, Douville H, Guérémy JF, Marquet P, Planton S, Royer J-F, Tyteca S (2005) Description and validation of CNRM-CM3 global coupled climate model. Note de Centre du GMGEC no. 103, Décembre 2005. Available from: http://www.cnrm.meteo.fr/scenario2004/paper_cm3.pdf

Sitch S, Smith B, Prentice IC, Arneth A, Bondeau A, Cramer W, Kaplan JO, Levis S, Lucht W, Sykes MT, Thonicke K, Venevsky S (2003) Evaluation of ecosystem dynamics, plant geography and terrestrial carbon cycling in the LPJ dynamic global vegetation model. Glob Chang Biol 9:161-185

Solomon S, Qin D, Manning M, Chen Z, Marquis M, Averyt KB, Tignor M, Miller HL (eds) (2007) Climate change 2007: the physical science basis. Cambridge University Press, Cambridge

Steffen K, Thomas RH, Rignot E, Cogley JG, Dyurgerov MB, Raper SCP, Huybrechts P, Hanna E (2010) Cryospheric contributions to sea-level rise and variability. In: Church JA, Woodworth PL, Aarup T, Wilson WS (eds) Understanding sea-level rise and variability. Wiley, Oxford. doi:10.1002/9781444323276.ch7

Stroeve JC, Kattsov V, Barrett AP, Serreze MC, Pavlova T, Holland MM, Meier WN (2012) Trends in Arctic sea ice extent from
CMIP5, CMIP3 and observations. Geophys Res Lett 39:L16502. doi:10.1029/2012GL052676

Taylor KE (2001) Summarizing multiple aspects of model performance in a single diagram. J Geophys Res 106(D7):7183-7192. doi:10.1029/2000JD900719

Taylor KE, Stouffer RJ, Meehl GA (2009) A summary of the CMIP5 experiment design, Lawrence Livermore National Laboratory report, $32 \mathrm{pp}$. Available online at http://cmip-pcmdi.llnl.gov/ cmip5/docs/Taylor_CMIP5_design.pdf

Timmermann R, Goosse H, Madec G, Fichefet T, Ethe C, Dulière V (2005) On the representation of high latitude processes in the ORCA-LIM global coupled sea ice-ocean model. Ocean Model 8:175-201

Tjiputra JF, Assmann K, Bentsen M, Bethke I, Otterå OH, Sturm C, Heinze C (2010) Bergen earth system model (BCM-C): model description and regional climate-carbon cycle feedbacks assessment. Geosci Model Dev 3:123-141. doi:10.5194/gmd-3-1232010

UNFCCC (1992) CCC/INFORMAL/84 GE.05-62220 (E) 200705

Valcke S (2006) OASIS3 user guide (prism_2-5), PRISM report no 2, 6th edn. CERFACS, Tolouse

van Vuuren DP, den Elzen MGJ, Lucas PL, Eickout B, Strengers BJ, van Ruijven B, Wonink S, van Houdt R (2007) Stabilizing greenhouse gas concentrations at low levels: an assessment of reduction strategies and costs. Clim Change 81:119-159. doi: 10.1007/s/10584-006-9172-9

Wada Y, van Beek LPH, SpernaWeiland FC, Chao BF, Wu YH, Bierkens MFP (2012) Past and future contribution of global groundwater depletion to sea-level rise. Geophys Res Lett 39:L09402. doi:10.1029/2012GL051230

Wang M, Overland JE (2009) A sea ice free Arctic within 30 years? Geophys Res Lett 36:L07502

Wang M, Overland JE (2012) A sea ice free summer Arctic within 30 years-an update from CMIP5 models. Geophys Res Lett. doi:10.1029/2012GL052868

Washington WM, Knutti R, Meehl GA, Teng H, Tebaldi C, Lawrence D, Lawrence B, Strand WG (2009) How much climate change can be avoided by mitigation? Geophys Res Lett 36:L08703. doi: 10.1029/2008GL037074

Wolff JO, Maier-Reimer E, Legutke S (1997) The Hamburg ocean primitive equation model. DKRZ technical report no. 13, Deutsches Klimarechenzentrum, Hamburg

Yin J (2012) Century to multi-century sea level rise projections from CMIP5 models. Geophys Res Lett 39:L17709. doi:10.1029/ 2012GL052947

Zhang X, Walsh JE (2006) Toward a seasonally ice-covered arctic ocean: scenarios from the IPCC AR4 model simulations. J Clim 19:1730-1747 